\title{
Een huis, een thuis?
}

Citation for published version (APA):

Verbeek, H. (2021). Een huis, een thuis? Hoe de zorgomgeving bijdraagt aan 'het dagelijks leven van kwetsbare ouderen. Academische Werkplaats Ouderenzorg Limburg.

https://doi.org/10.26481/spe.20210709hv

Document status and date:

Published: 09/07/2021

DOI:

10.26481/spe.20210709hv

Document Version:

Publisher's PDF, also known as Version of record

\section{Please check the document version of this publication:}

- A submitted manuscript is the version of the article upon submission and before peer-review. There can be important differences between the submitted version and the official published version of record.

People interested in the research are advised to contact the author for the final version of the publication, or visit the DOI to the publisher's website.

- The final author version and the galley proof are versions of the publication after peer review.

- The final published version features the final layout of the paper including the volume, issue and page numbers.

Link to publication

\footnotetext{
General rights rights.

- You may freely distribute the URL identifying the publication in the public portal. please follow below link for the End User Agreement:

www.umlib.nl/taverne-license

Take down policy

If you believe that this document breaches copyright please contact us at:

repository@maastrichtuniversity.nl

providing details and we will investigate your claim.
}

Copyright and moral rights for the publications made accessible in the public portal are retained by the authors and/or other copyright owners and it is a condition of accessing publications that users recognise and abide by the legal requirements associated with these

- Users may download and print one copy of any publication from the public portal for the purpose of private study or research.

- You may not further distribute the material or use it for any profit-making activity or commercial gain

If the publication is distributed under the terms of Article $25 \mathrm{fa}$ of the Dutch Copyright Act, indicated by the "Taverne" license above, 


\section{Een huis, een thuis?}

Hoe de zorgomgeving bijdraagt aan het dagelijks leven van kwetsbare ouderen

Hilde Verbeek

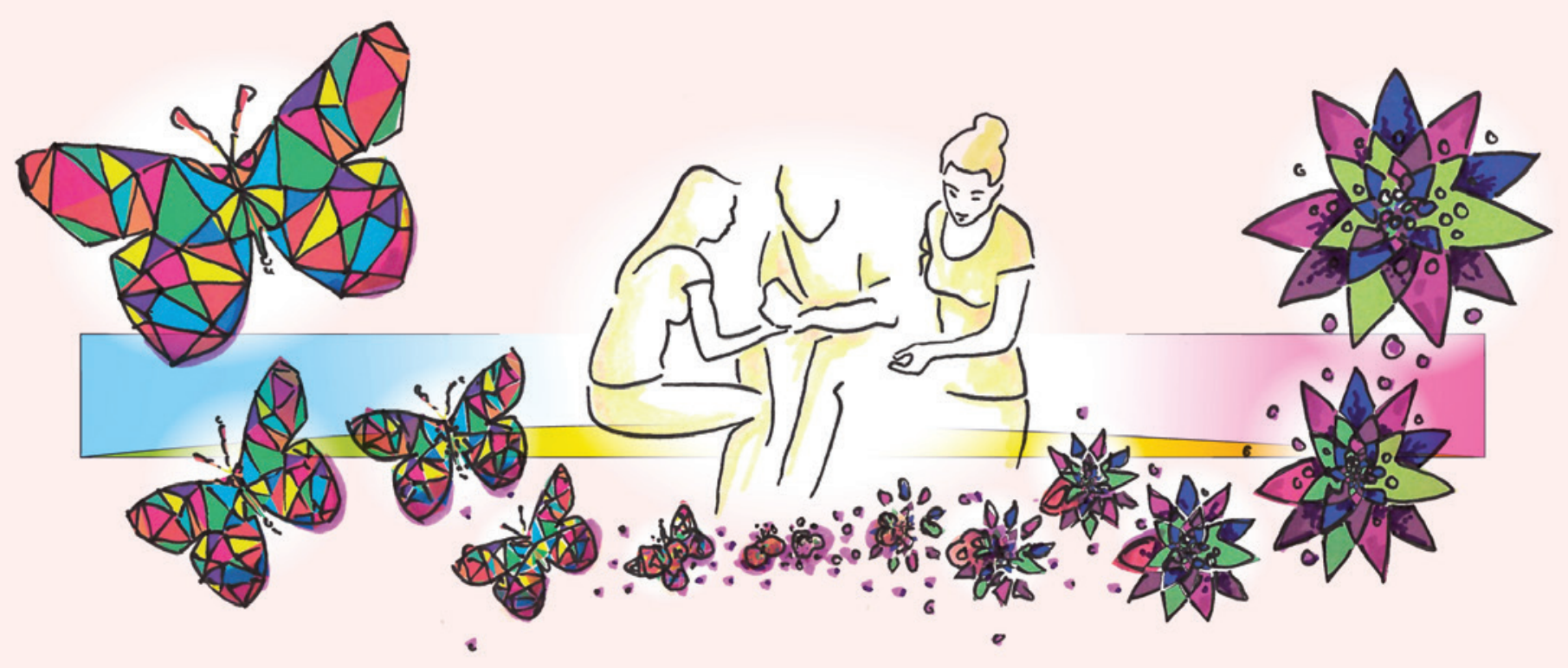




\section{Colofon}

\section{Een huis, een thuis?}

Hoe de zorgomgeving bijdraagt aan het dagelijks leven van kwetsbare ouderen

eindredactie Suzanne Rijcken

illustraties Pieter Jansen

opmaak BONNÉ+JAN

druk Drukkerij Pietermans

Publicatie is online beschikbaar via de website van de

Academische Werkplaats Ouderenzorg Limburg | www.awolimburg.n

Inaugurele rede uitgesproken ter aanvaarding van de bijzondere leerstoe

Zorgomgeving voor kwetsbare ouderen

De Academische Werkplaats Ouderenzorg Limburg (AWO-L) is een structurele samenwerking tussen

de Universiteit Maastricht, Zuyd Hogeschool, Gilde Zorgcollege, VISTA college en 9 zorgorganisaties:

Faculty of Health, Medicine and Life Sciences

MeanderGroep Zuid-Limburg, Sevagram, Envida, Cicero Zorggroep, Zuyderland, Vivantes, Land van Horne,

Maastricht University

() Hilde Verbeek, Maastricht, 2021

Maastricht, 9 juli 2021 
Geachte rector, gewaardeerde collega's,

lieve familie en vrienden,

Ik sta graag even stil bij de bijzondere omgeving waarin we nu zijn, de Sint Janskerk op het Vrijthof in Maastricht. Een kerk is het huis van God, maar ook van de gemeenschap. Normaliter vinden oraties van de Universiteit Maastricht plaats in de Aula van de Minderbroedersberg, maar ik heb vandaag de eer hier voor u te mogen staan. Wat doet deze omgeving met u en mij? De fysieke omgeving van

de kerk is imposant en zorgt ervoor dat we stiller zijn in ons gedrag dan anders. Dit in tegenstelling tot bijvoorbeeld een kroeg of discotheek waar uitbundige muziek op staat en je lekker kunt dansen. Het ligt niet alleen aan de fysieke omgeving. Ook de plechtigheid van de ceremonie, de gebruiken die hierbij horen, maken dat we in een bepaalde stemming zijn. Zelf ben ik positief gespannen, en u?

De omgeving vormt ons gedrag en functioneren in het dagelijks leven. Het is het resultaat van jouw

而

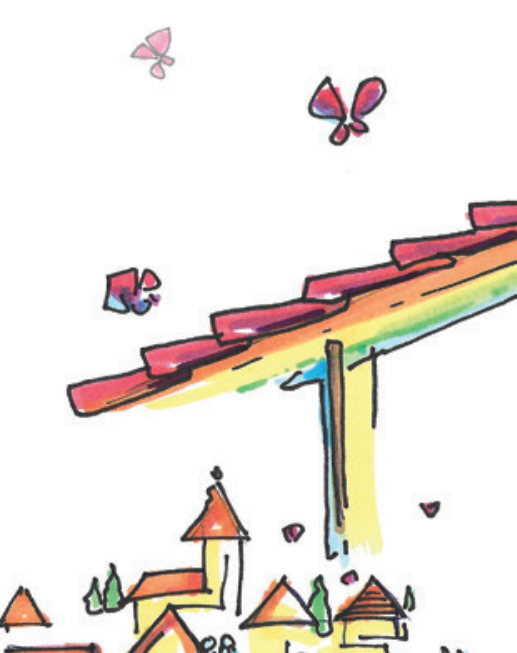

$\Delta$

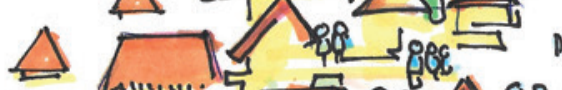
$\Delta \triangle$ A $\square \rightleftarrows$ $\Delta$ interactie als persoon met de omgeving om je heen. Hoe werkt dit principe wanneer je ouder wordt? Ouder worden komt met gebreken zeggen ze. De dingen in je dagelijks leven kunnen moeilijker worden. Bijvoorbeeld omdat je zaken vergeet, of omdat je lichamelijke problemen hebt waardoor je minder makkelijk vooruit kunt. Daardoor word je afhankelijker van je omgeving. Al in 1973 heeft Lawton als een van de eersten het zogenaamde person-environment fit model ontwikkeld. ${ }^{1}$

Dit model zegt dat er een match, een overeenkomst moet zijn tussen dat wat de omgeving van je vraagt en jouw eigen vaardigheden, behoeften en voorkeuren om zo adequaat gedrag te bevorderen

Met mijn leerstoel onderzoek ik hoe de

zorgomgeving het dagelijks leven en functioneren van kwetsbare ouderen beïnvloedt. Om dit proces te beschrijven, heb ik een model ontwikkeld. ${ }^{2}$ De zorgomgeving bestaat uit drie componenten: fysieke, sociale en organisatorische. De fysieke omgeving bestaat uit de architectuur, hoe de gebouwde omgeving eruitziet, de lay-out van het gebouw, de inrichting of decor en buitenruimte, zoals een tuin. Vervolgens is er de sociale omgeving, oftewel de interacties die je aangaat met anderen in je omgeving. Dit zijn bijvoorbeeld medebewoners in je huis, je familie en naasten, vrienden, vrijwilligers, kinderen. En het bredere sociale netwerk, de context waarin je woont, zoals de buurt, scholen, ondernemers, verenigingen. Het dak van de zorgomgeving wordt gevormd door de organisatorische context, zoals hoe de zorg- en dienstverlening wordt georganiseerd. Belangrijk hierbij is de organisatiecultuur: de gedachten, aannames, visie en waarden die medewerkers hebben en onderliggend zijn aan het gedrag om de zorg- en dienstverlening te realiseren.

Idealiter is het huis waar je woont ook je thuis, maar bij kwetsbare ouderen die intensieve zorg nodig hebben, is dit lang niet altijd het geval. Het doel van mijn oratie is om het belang van je thuis voelen te duiden voor je dagelijks leven en functioneren, hoe de (zorg)omgeving daaraan kan bijdragen en waarom hier juist inter- en transdisciplinair wetenschappelijk onderzoek voor nodig is. Mijn boodschap is dat we af moeten van het strikte onderscheid tussen thuiszorg en verpleeghuiszorg en dat we moeten zoeken naar creatieve oplossingen, waar ouderen hun leven lang kunnen blijven wonen en intensieve zorg kunnen ontvangen, 24 uur per dag als het nodig is. 
Thuis

6
De meeste mensen willen thuis wonen, ook wanneer ze oud zijn en de behoefte aan hulp en ondersteuning in het dagelijks leven groeit. Het beleid is hier ook op gericht: mensen ondersteunen zodat ze zo lang mogelijk thuis kunnen wonen.

Thuis is de plek waar je woont, oftewel je woning. Het is een samentrekking van de woorden 'te' en 'huis' en werd tot in 1900 nog vaak met een apostrof als t'huis geschreven. Nu hebben de woorden te en huis voor ons echter een andere betekenis, juist tegengesteld aan thuis. Een tehuis is een voorziening, een instelling waar mensen wonen die verzorging nodig hebben. Het verpleegtehuis is vaak het schrikbeeld van ouderen. Toch klinkt, nu de verzorgingshuizen gesloten zijn, er ook regelmatig de kreet "we moeten weer terug naar de verzorgingstehuizen of bejaardentehuizen"

Ik betwijfel dat en denk dat we niet letterlijk terug willen naar de tehuizen van toen. Het is een uiting van een onderliggende behoefte. De behoefte om wanneer je ouder en kwetsbaarder wordt, samen te zijn in een omgeving met anderen. Die naar je omkijken, die voor je zorgen, die je zien. De behoefte aan een thuis.

Thuis is namelijk vooral een gevoel: je voelt je ergens thuis. Dit is een positieve gewaarwording. Bijvoorbeeld wanneer mensen op vakantie zeggen "Het voelt echt als thuis". Er is veel wetenschappelijk onderzoek gedaan naar wat maakt wanneer je je thuis voelt en dit is ook specifiek onderzocht bij ouderen. ${ }^{4,5}$ Een thuisgevoel ontstaat vanuit de interactie die je als persoon hebt met je omgeving. ${ }^{6}$ Het thuisgevoel is heel persoonlijk, en verbonden met je eigen ervaringen en emoties. Het komt niet in een dag; het is een gevoel dat je ontwikkelt in de tijd. Thuisgevoel betekent onafhankelijkheid, je eigen keuzes kunnen maken en controle uitoefenen over situaties. Thuis betekent ook veiligheid: enerzijds de afwezigheid van potentieel gevaar en anderzijds de aanwezigheid van bescherming en beschutting., ${ }^{4,5,6}$ Veiligheid is ook geborgenheid. Thuis als veilige haven.

Daarnaast is thuis gerelateerd aan je identiteit, aan wie je bent als persoon. Daarom aarzelen ouderen vaker om te verhuizen dan jongere leeftijdsgroepen. Ze houden vast aan hun huis vanwege hun herinneringen; het is onderdeel van hun identiteit geworden en ze hechten sterker aan bestaande sociale netwerken in de eigen buurt. $5,7,8$

Maar wat als thuis niet meer thuis is? Wat als de woning waarin je woont niet meer de 
onafhankelijkheid, de veiligheid en geborgenheid kan bieden? Dat thuis je niet meer in staat stelt om te zijn wie je bent? Dat thuis je niet lange ondersteunt om je dagelijks leven te leiden zoals je dat zou willen. Of omdat je bijvoorbeeld eenzaam bent en niemand meer ziet. Of dat je onafhankelijkheid en zelfstandigheid verminderen doordat je moeilijker ter been bent en er geen voorzieningen in de buurt zijn?

Dan verhuis je.

In een mensenleven verhuizen we regelmatig gemiddeld zo'n zeven keer volgens het Centraal Bureau voor de Statistiek. Onze wensen en behoeften omtrent leefomgeving veranderen, afhankelijk van de levensfase. Denk aan jongeren die gaan studeren en op zichzelf gaan wonen, of wanneer mensen gaan samenwonen; jonge gezinnen willen vaak in een groter huis met tuin wonen, dicht bij de school. Wanneer de kinderen het huis uit zijn, is het huis wellicht weer te groot. Mensen scheiden of komen juist bij elkaar.

Wanneer we ouder worden en onze behoefte aan ondersteuning van anderen toeneemt, lijken we dit principe te vergeten. Nu zijn het nog te vaak onaangename gebeurtenissen die ertoe leiden dat ouderen gaan verhuizen. Dit worden ook wel push-factoren genoemd: je wordt weggeduwd van je huidige plek..$^{91} 10$ Voorbeelden zijn toenemende zorgbehoeften en ingrijpende levensgebeurtenissen, zoals het overlijden van je partner.

"We houden nog te

lang vast aan het idee

van thuis als zijnde de

woning waarin je altijd

gewoond hebt."

Maar verhuizen kan ook aantrekkelijk zijn, juist voor ouderen. Deze zogenaamde pull-factoren liggen vooral op het gebied van sociale voordelen, zoals dichter bij voorzieningen en sociale contacten wonen, veiligheid en bekendheid met de nieuwe woning en de wens tot een meer passende leefomgeving en woning.,10 Ouderen zelf geven aan dat wanneer ze sterker afhankelijk worden van anderen hun woonwensen ook veranderen. Inzicht in de motieven voor ouderen om te willen verhuizen, is belangrijk bij de keuze voor de beste zorgomgeving.

We houden nog te lang vast aan het idee van thuis als zijnde de woning waarin je altijd gewoond hebt. Het strikte onderscheid tussen thuiszorg en verpleeghuiszorg werkt hierbij belemmerend. Er is momenteel een tekort aan passende woonvormen voor ouderen die intensieve zorg nodig hebben en dit zorgt voor onnodig leed in het dagelijks leven. Soms maakt de omgeving waarin deze ouderen wonen hen eerder ziek dan dat het hen ondersteun om hun dagelijks leven te leiden.

Naar mijn idee romantiseren we hierbij enerzijds het beeld van thuis wonen in de eigen woning als beste plek voor ouderen. Ook al is dit normaal gesproken de wens van ouderen zelf, voor kwetsbare ouderen met een intensieve zorgvraag, bijvoorbeeld mensen met dementie, is dit vaak niet de optimale keuze. Omdat ze soms als het ware opgesloten zitten in hun eigen huis, achter de voordeur. Niet in staat om contact te maken met anderen, of deel te nemen aan activiteiten in de gemeenschap. De zorg is teveel om te dragen voor naasten en zij gaan er aan onderdoor wanneer deze situatie te lang duurt.
Verhuizen naar het verpleeghuis hoeft niet slech te zijn voor ouderen, en voor mantelzorgers kan het juist beter zijn, omdat het hen ontlast. ${ }^{11}$ Ons onderzoek, uitgevoerd onder ruim 2000 ouderen met dementie en hun naasten in acht Europese landen, laat zien dat kwaliteit van zorg vergelijkbaar is, net als kwaliteit van leven.12 Daarnaast lijkt zorg thuis wellicht goedkoper, maar ook dat is betwistbaar, juist voor de groep kwetsbare ouderen die intensieve zorg nodig heeft ${ }^{13,4}$

Anderzijds is de beeldvorming over verpleeghuiszorg onnodig negatief. In de media horen we vrijwel uitsluitend de zwartgallige verhalen: over pyjamadagen, ouderen die te lang in bed moeten liggen en een tekort aan deskundige medewerkers. Kortom, niemand wil in een verpleeghuis wonen. Het stereotype beeld van het verpleeghuis is dat van een oudere die aan een tafel zit en de hele dag vrijwel niets doet, hooguit een potje bingo. De innovatiekracht die vanuit de sector gaande is krijgt te weinig aandacht.

Toch zit er in deze stereotypering wellicht wel een kern van waarheid. Onder andere ons eigen onderzoek heeft meermaals laten zien dat bewoners in reguliere verpleeghuizen de meeste tijd stil zitten, passief en niet betrokken zijn. ${ }^{15,16}$ Terwijl 
de beweegnorm ook voor deze ouderen 2,5 uur per week is, oftewel ruim 30 minuten per dag. ${ }^{17}$ Dat is matig intensief bewegen waarvan je gaat hijgen. Ouderen zijn ook bang hun autonomie te verliezen in het verpleeghuis, omdat ze ineens mee moeten in het ritme van een organisatie en dingen die eerder voor hen belangrijk waren in het leven niet meer voort kunnen zetten. ${ }^{18}$ Daarbij worden taken of bezigheden vaak onnodig overgenomen door zorgverleners.

"Zoals het klokje thuis tikt, tikt het nergens anders. Mijn vrouw wilde het liefste samen met mij thuis blijven wonen, maar dat werd te gevaarlijk en belastend door haar dementie. Nu zit ze hier in het verpleeghuis. Hier voelt het niet als thuis. De dingen die mijn vrouw thuis deed, kan ze hier niet. Mijn rol als man is hier ook anders. We voelen ons verzorgd, maar niet thuis."

De verhuizing van thuis naar het verpleeghuis vinden ouderen en hun naasten vaak dramatisch. De structuur en het leven zoals dat thuis wordt geleefd verdwijnt en men moet zich aanpassen aan de organisatie van het verpleeghuis. Dit kan hun kwaliteit van leven ernstig bedreigen. Wetenschappelijk onderzoek laat zien dat he belangrijk is om de levensstijl in de thuissituatie te leren kennen en ervoor te zorgen dat deze voortgezet kan worden in het verpleeghuis. ${ }^{20,2}$

Veel medewerkers in de zorg weten dit, maar vinden het lastig om hiernaar te handelen.

Het is mijn overtuiging dat we bestaande tradities in verpleeghuizen kunnen doorbreken en deze kunnen omvormen tot woningen waar intensieve zorg geboden wordt, in de gemeenschap. Laten we muren doorbreken, ook taalkundig en het thuisgevoel vooropplaatsen. Stoppen met de lelijke termen intra- en extramuraal. Nu denkt u misschien, lossen we met het veranderen van onze taal alles op? Nee, dat denk ik niet. Maar ik vin wel dat we zorgvuldiger naar ons woordgebruik dienen te kijken. Want zoals Angela Merkel eind vorig jaar zei: "Taal is de voorloper van het handelen. Wanneer taal de verkeerde kant op gaat, gaat ook ons handelen de verkeerde kant op". Ons gedrag en handelen wordt in de zorg mede bepaald door de termen die we gebruiken, zonder na te denken over wat die echt voor mensen betekenen. Alsof we nog een extra muur om ouderen heen bouwen zodra ze gaan verhuizen naar het verpleeghuis, om hen af te zonderen van de rest van de maatschappij. Het zorgt voor een onnodige scheiding tussen thuis en het verpleeghuis, die niet meer realistisch is.
Er is een behoefte aan nieuwe, alternatieve vormen van wonen met intensieve zorgverlening die het thuisgevoel, de eigen regie en identiteit ondersteunen, zoals een recente peiling va Alzheimer Nederland laat zien. ${ }^{22}$ Laten we hierbij kiezen voor levenslange oplossingen, niet als een tussenvorm voor thuis en het verpleeghuis. Want dan moet je weer verhuizen, je thuisgevoel opnieuw ontwikkelen en dit kan het welzijn negatief beïnvloeden. Daarbij slagen tussenvormen vaak niet. Wanneer is het goede moment voor verhuizing? Het risico is groot dat je nog 'te goed bent voor verhuizing', maar wanneer je daadwerkelijk wi verhuizen, dan is de zorg te zwaar en kan deze nie meer geboden worden. ${ }^{23}$

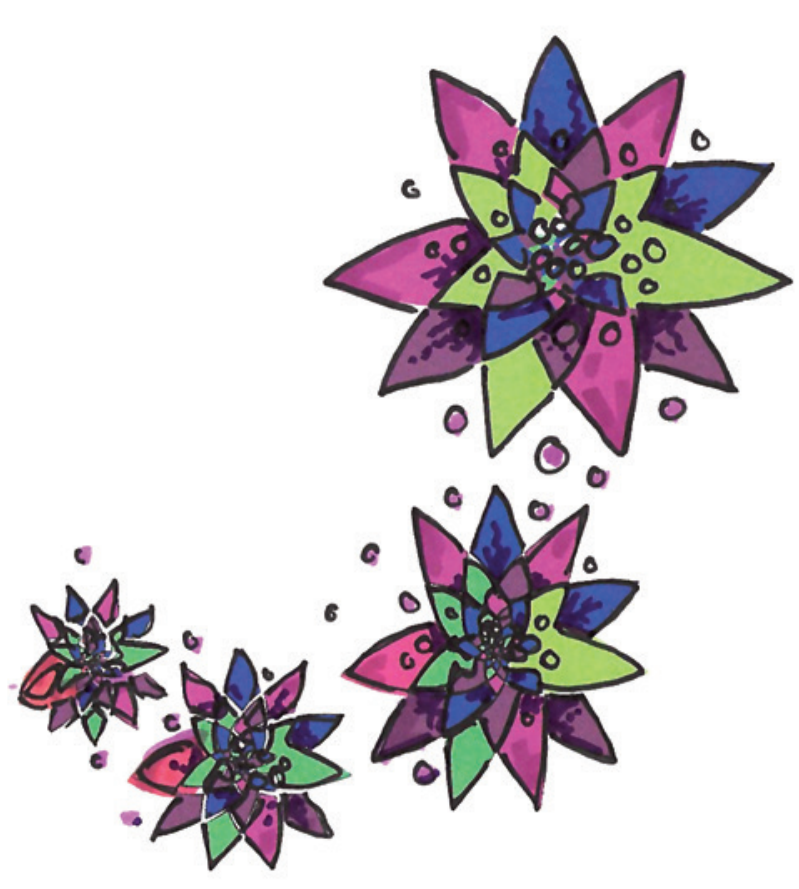




\section{Zorgomgeving}

\section{als je thuis}

12
Een huis is niet automatisch een thuis, terwijl dat laatste wel voor iedereen het doel zou moeten

zijn, ongeacht je hulpbehoevendheid. Ik bestudee wat de zorgomgeving betekent voor het dagelijks leven en functioneren van ouderen, met zij die intensieve zorg en ondersteuning nodig hebben, zoals mensen met dementie. Ongeveer een derde van hen woont in collectieve woonvormen, zoals verpleeghuizen, woonzorgcentra of groepswoningen.

In eerste instantie denken we bij de omgeving vaak aan de stenen en wat je kunt aanraken, oftewel de fysieke omgeving. De fysieke omgeving beïnvloedt het dagelijks leven en functioneren van ouderen..$^{24,25}$ Zichtlijnen bevorderen bijvoorbeeld de oriëntatie als ik mijn kamer uitloop zie ik direct waar ik naartoe kan, bijvoorbeeld de buitenruimte, zodat ik daar zelf naartoe kan lopen. De fysieke omgeving helpt ook betekenisvolle activiteiten en relaties tot stand te brengen. Een goede fysieke omgeving betekent echter niet dat bewoners deze ook automatisch goed gebruiken. ${ }^{26}$ Verpleegkundigen en verzorgenden spelen een sleutelrol. Er kan wel een prachtige buitenruimte zijn, maar als de deur op slot zit, stimuleert het bewoners niet om er gebruik van te maken.
Een persoon kan niet gescheiden worden van zijn of haar omgeving en bestaat door de relaties me anderen en de betekenis die daaraan gegeven wordt. Zorg ontstaat dan ook in dynamische relaties tussen mensen in een bepaalde context en is een wederkerig proces. ${ }^{27}$ Voor het schrijven van deze oratie heb ik gezocht in het woordenboek en op internet naar de betekenis van het woord 'zorg'. Ik ben verschillende definities en beschrijvingen tegengekomen die als volgt samengevat kunnen worden:

- Zorg is "Wat je doet voor iets dat of iemand die hulp of aandacht nodig heeft". Aandacht, attentie, hoede, behartiging, toewijding zijn vergelijkbare synoniemen die ik tegenkwam. Al deze duidingen hebben vooral een positieve klank of betekenis.

- Een tweede betekenis die naar voren kwam, komt echter vanuit een negatiever sentiment. Het woordenboek duidt zorg bijvoorbeeld ook als ongerustheid, angst, bemoeienis, benauwdheid, kommernis en kwelling. Het heeft betrekking op "het gevoel dat er iets onaangenaams zal gebeuren." 
Beide stromingen lijken samen te vallen met een "behoedzame overweging", zoals het

Wikiwoordenboek zorg duidt. Deze term doet recht aan de dynamiek in de langdurige ouderenzorg

waar je te maken hebt met een netwerk van relaties. Mensen die ieder op hun eigen manier bijdragen aa de ondersteuning en zorg in het dagelijks leven van anderen, waaronder:

1 De oudere zelf, die hulp en ondersteuning nodig heeft om zijn/haar dagelijks leven te kunnen leiden;

2 Het sociale, informele netwerk van de oudere, zoals naasten, familie, vrienden, kennissen, vrijwilligers, mensen uit de buurt of wijk. Bijvoorbeeld een partner, kinderen of kleinkinderen, de buurvrouw, de voetbalclub of harmonie. Vanuit een bestaande persoonlijke band, maar dat hoeft niet. Vrijwilligers bijvoorbeeld zijn veelal mensen zonder een bestaande relatie met de oudere.

3 Medewerkers: beroepskrachten, oftewe professionals die zijn opgeleid en betaald krijgen om de zorg- en dienstverlening te bieden vanuit een formele relatie. In de langdurige ouderenzorg zijn vele professionals met verschillende achtergronden betrokken.
Idealiter zijn ouderen, hun naasten en medewerker gelijkwaardige partners in de zorg. Samen hebben ze hetzelfde belang, namelijk de oudere die de intensieve zorg en ondersteuning nodig heeft zo goed helpen dat deze zijn of haar dagelijks leven kan leiden zoals gewenst. In praktijk is de relatie tussen naasten en zorgmedewerkers echter ingewikkeld en begrijpen we deze nog onvoldoende. Een partnerschap komt niet altijd tot uiting. Bijvoorbeeld omdat ouderen en hun naasten afhankelijk zijn van professionals. Daarnaast zijn er conflicten in verwachtingen en rollen en verloopt de communicatie moeilijk. ${ }^{28,29}$

\section{“Een persoon kan niet}

gescheiden worden van

zijn of haar omgeving en

bestaat door de relaties met anderen en de betekenis die je daaraan geeft."
Traditionele wetenschappelijke modellen stellen dat de 'informele' en 'formele' zorgverlening apart van elkaar bestaan, in plaats van als overlappend invloeden. Daarbij excluderen ze de oudere, de zorgontvanger, als potentieel actieve deelnemer in zijn of haar eigen zorgproces..$^{30}$ Juist de wederkerigheid in relaties is zo van belang. ${ }^{31}$ Wanneer zorgontvangers ook iets terug kunnen doen, geeft dat hen een gevoel van betekenis.

Kemp en collega's hebben een ander uitgangspunt ontwikkeld dat de sociale zorgomgeving beschrijft:

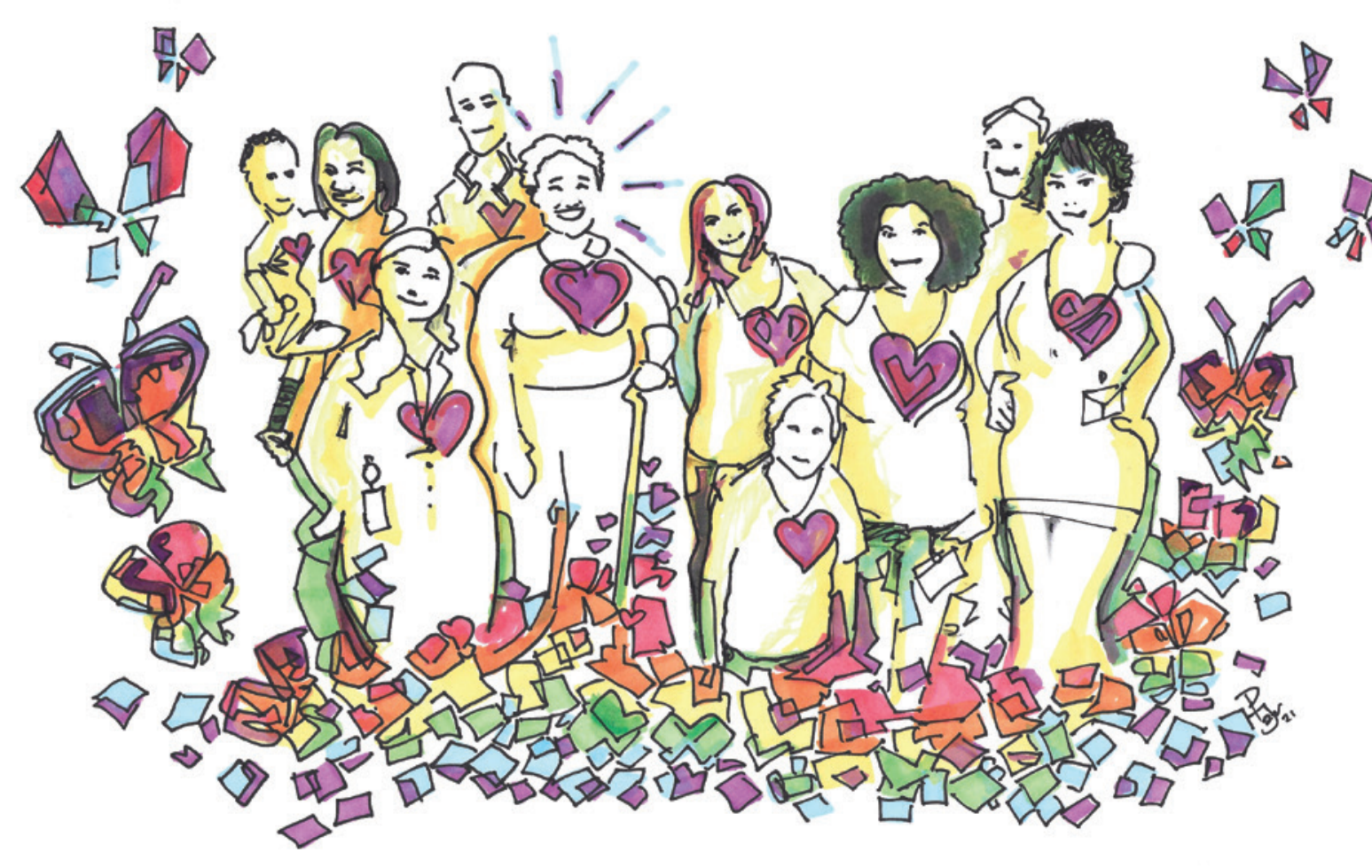

een 'Konvooi model'. ${ }^{30}$ Individuen zijn omgeven door een konvooi: een begeleidend en dynamisch netwerk van persoonlijke relaties dat dient als vehikel om sociale steun te bieden. Deze netwerken kunnen in de loop van de tijd veranderen. Kenmerken zijn bijvoorbeeld structuur (zoals de grootte, homogeniteit of stabiliteit), functie (geven of ontvangen van steun of juist uitwisselen) en adequaatheid (bijvoorbeeld tevredenheid). Er bestaan verschillende interventies die de fysieke en sociale omgeving veranderen om het welzijn en en sociale omgeving veranderen om het welzijn en 
De effectiviteit hiervan is echter zeer wisselend. Soms hebben ze positieve resultaten, maar soms ook niet of leiden ze zelfs tot verslechtering van het dagelijks leven. Dit komt doordat vaak slechts één aspect van de omgeving verandert. De fysieke omgeving verandert bijvoorbeeld door een nieuw gebouw. Of medewerkers passen de wijze waarop zij bewoners benaderen aan.

De organisatorische context en cultuur worden vaak vergeten, terwijl deze uiteindelijk beïnvloeden hoe de fysieke en sociale aspecten van de omgeving tot uiting komen. Onderzoek in Nederland naar kleinschalige woonvormen, waaronder mijn promotie-onderzoek, laten dit zien. Idealiter stimuleren deze woonvormen een thuisgevoel, met eigen regie voor bewoners. De mate waarin de zorgvisie achter het concept ook daadwerkelijk geïmplementeerd is in praktijk varieert sterk. ${ }^{32,33}$ Sommige kleinschalige woonvormen werken nog via traditionele werkwijzen, terwijl reguliere verpleeghuizen kenmerken van kleinschaligheid overnemen. Om uitkomsten daadwerkelijk te veranderen, dienen de fysieke, sociale èn organisatorische componenten met elkaar in overeenstemming te zijn., 34

Dit vraagt van een organisatie om zich continu aan te passen en dus te beschikken over bepaalde dynamische vaardigheden in haar strategische benadering. De theorie van dynamische vaardigheden onderscheidt drie activiteitenclusters: ${ }^{35}$

1 Sensing (het voelen): het zien en herkennen van kansen die zich in de zorgomgeving voordoen;

2 Seizing (het grijpen): het mobiliseren van

bronnen om de kansen te benutten en in waarde te vangen voor ouderen, hun naasten en medewerkers, en

3 Transforming (het transformeren); continu blijven vernieuwen om daadwerkelijke veranderingen te bereiken

Ik denk dat dit aanknopingspunten biedt voor de ouderenzorg, waar deze inzichten nog nauwelijks onderzocht zijn.

Innovatieve zorgomgevingen

Ouderen willen in een omgeving wonen waarin ze zich thuis voelen, waar de zorg zodanig georganiseerd is dat die past bij hun levensgeschiedenis, voorkeuren en behoeften, en inspeelt op hun restcapaciteit; wat kan ik nog wel en hoe kunnen we dat versterken. Het ontwerp van de zorgomgeving dient de agency, oftewel het vermogen tot handelen van ouderen te ondersteunen, aangepast aan hun voorkeuren wensen en behoeften. Ouderen, hun naasten en zorgverleners wegen continu 'goed leven', gericht op zaken als autonomie, welzijn, welbevinden van ouderen en 'veilig leven', gericht op het beperken van risico's en het bestrijden van ziekte-specifieke symptomen. Oftewel, steeds die behoedzame overweging maken wat voor deze persoon, op dit moment, in deze context, het beste past.

De zorgomgeving in de huidige praktijk is onvoldoende ingericht om een betekenisvol

bestaan en sociale betrokkenheid, uitgaande van de autonomie van ouderen, te realiseren. ${ }^{36}$ Bestaande tradities, denkbeelden, werkwijzen en de inrichting van werkprocessen staan vernieuwing en verandering in de weg. Ritmes en routines van de organisatie bepalen nog voor een groot gedeelte het handelen van medewerkers en het dagelijks leven van ouderen. Verpleeghuizen scheiden mensen vaak van de rest van de wijk en er is weinig interactie met de lokale gemeenschap. ${ }^{37}$ Bewoners komen niet of nauwelijks buiten. Ouderen met dementie verblijven onnodig vaak op een gesloten afdeling, terwijl open instellingen ook mogelijk zijn. Mits de zorgomgeving goed is ingericht. De coronapandemie, met nadruk op restrictieve maatregelen en nog striktere scheiding van bezoek en bewoners, heeft dit nog verergerd. ${ }^{38}$
Op verschillende plekken, zowel nationaal als internationaal, worden daarom innovatieve woonzorgconcepten ontwikkeld, waarbij men experimenteert met radicale veranderingen in de zorgomgeving, zowel in fysieke, sociale als organisatorische zin. Voorbeelden zijn divers en ook de initiatiefnemers lopen sterk uiteen. Zo zijn er initiatieven van burgers zelf, die willen ondersteunen dat ouderen die intensieve zorg en ondersteuning nodig hebben ook in hun eigen dorp oud kunnen worden. Zoals Zorgcoöperatie Hoogeloon of 't Zorghuys in Ysselsteyn. Andere initiatieven ontstaan vanuit ondernemers, veelal op kleine schaal. Ook woningbouwcorporaties, gemeenten en reguliere zorgaanbieders werken met elkaar

aan nieuwe initiatieven, vanuit een breder maatschappelijk perspectief.

Zorgboerderijen zijn een voorbeeld van een innovatief woonzorgconcept dat de laatste jaren sterk in opkomst is. Nederland loopt voorop in de ontwikkeling van zorgboerderijen, met name als alternatief voor reguliere ouderenzorg. Als eerste wereldwijd hebben zorgboerderijen het concept van dagopvang en - behandeling verbreed naar 24-uurszorg met woonzorgboerderijen als volwaardig alternatief voor reguliere verpleeghuiszorg. Er zijn verschillende varianten, 
De afgelopen jaren heb ik verschillende

onderzoeken naar zorgboerderijen opgezet. Het promotieonderzoek van Bram de Boer laat zien dat bewoners van zorgboerderijen een actiever dagelijks leven hebben dan bewoners van reguliere verpleeghuizen, met meer sociale interacties. Bovendien komen deze bewoners vaker buiten, hetgeen samenhangt met een betere kwaliteit van leven. ${ }^{15,39}$ De kwaliteit van de zorgverlening lijkt niet te verschillen van die van de reguliere zorg en naasten zijn vaak positiever over de mate waarin zorgverlening wordt afgestemd op persoonlijke voorkeuren en behoeften. ${ }^{40,4}$

Daarnaast is er anekdotisch bewijs dat ouderen hun laatste levensfase anders ervaren. Op zorgboerderijen lijken ouderen langer te functioneren op een relatief hoger niveau en komen dan plotseling te overlijden, bijvoorbeeld door een longontsteking of andere acute situatie. Dit in tegenstelling tot wat men in reguliere verpleeghuizen observeert, een vaak langzame achteruitgang, waarbij ouderen steeds meer van hun functioneren verliezen. Samen met mijn collega Judith Meijers werken we aan wetenschappelijk onderzoek op dit terrein van

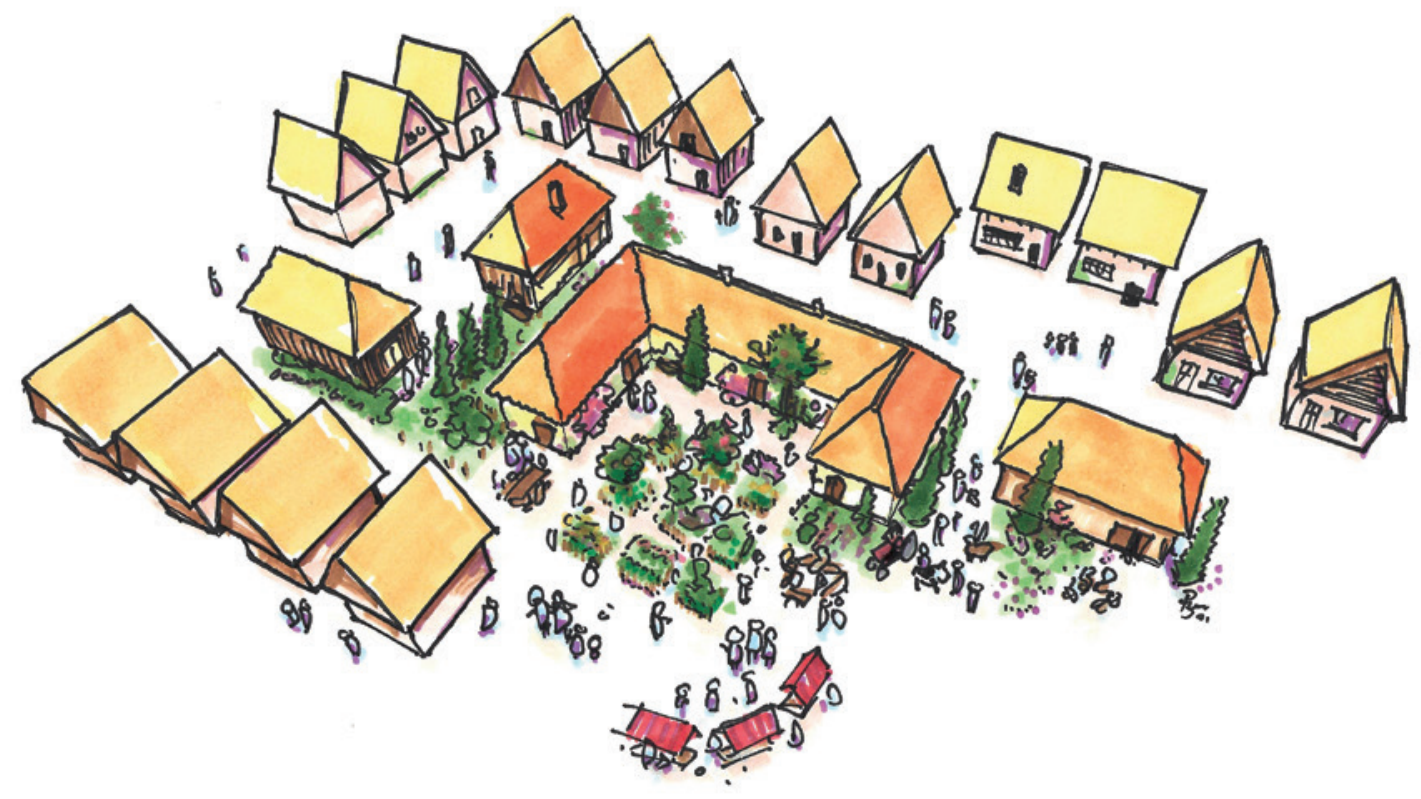

zorg in de laatste levensfase, hoe deze zorg ervaren wordt en of we verschillen zien tussen reguliere zorg en zorgboerderijen. Ik wil meer inzicht krijge in waarom zorgboerderijen en andere innovatieve woonvormen effect hebben op het functioner van ouderen. Ik wil vooral beter begrijpen wat de actieve ingrediënten uit hun zorgomgeving zijn (fysiek, sociaal, organisatorisch), hoe deze met elka samenhangen en hoe ze het functioneren van de ouderen kunnen beïnvloeden.

Het goed meten van uitkomsten is van groot belang om mogelijke effecten van de zorgomgeving op het dagelijks leven en het functioneren van kwetsbar ouderen vast te stellen. Het gedrag van bijvoorbeeld ouderen met dementie en de onderliggende determinanten van het gedrag variëren namelijk over contexten en tijd, zowel op een dag als over meerdere dagen. Huidige methoden hebben hun oorsprong in klinische beoordelingsinstrumenten en meten een samenvatting van het oordeel over het gedrag of functioneren over een bepaalde periode. Meestal wordt aan zorgverleners, zoals familie of medewerkers, of aan ouderen zelf, gevraagd of ze terug kunnen kijken op een bepaalde periode, bijvoorbeeld afgelopen week. Zij denken dan terug aan die periode en geven een oordeel over het voorkomen van bepaald gedrag of in hoeverre iemand gemiddeld over die periode in staat was om nog zelfstandig activiteiten in het dagelijks leven te ondernemen.

Deze meetmethoden zijn echter onvoldoende bruikbaar om de dynamiek in het dagelijks functioneren te meten, omdat ze resulteren in een gemiddeld of samengevat oordeel. Daarbij is er een grote kans op een herinneringsbias, waarbij deelnemers zich niet meer goed herinneren wat er precies heeft plaatsgevonden of bepaalde relevante details weglaten. Dit zorgt voor een overof onderrapportage van gedrag en functioneren. Daarbij worden oordelen van mensen ook beïnvloed door andere factoren, zoals ervaren belasting.

Het dagelijks leven is dynamisch, en afhankelijk van de zorgomgeving waarin iemand zich bevindt, zeker bij ouderen met intensieve zorgvragen zoals dementie. We moeten daarom op zoek naar meetinstrumenten die ook zelf dynamisch kunnen meten, direct in het dagelijks leven. Ik zie daarbij veel potentie in zogenaamde Ecological Momentary Assessments (EMA) om een beter begrip te verkrijgen van de impact die een zorgomgeving heeft en hoe deze invloed uitoefent op het dagelijks leven en welbevinden van ouderen met een intensieve zorgvraag. Op deze manier meet je ervaringen en 
gedrag van personen op het moment dat ze ook daadwerkelijk plaatsvinden: real-time, zonder vertraging, en in hun natuurlijke context en situatie over de tijd heen. ${ }^{42}$

Ik zie drie verschillende voordelen die deze techniek heeft boven de klassieke meetmethoden, en zal deze toelichten aan de hand van de verschillende termen. Als eerste refereert de term Ecological naar de natuurlijke omgeving waarin situaties plaatsvinden en de gegevens worden verzameld; niet in een experimenteel laboratorium of achteraf wanneer je in een andere omgeving of situatie bent. Als tweede refereert de term Momentary naar de focus van de meting: in het moment, dicht bij de daadwerkelijke ervaring waardoor de herinneringsbias afneemt. Als laatste refereert de term Assessment naar de verschillende punten van gegevensverzameling. Niet op één moment, maar juist over de tijd heen, zodat je inzicht krijgt in gedrag en functioneren over verschillende situaties en contexten heen. Dit geeft een beter inzicht in de dynamische variatie van het dagelijks leven en wat de onderliggende determinanten kunnen zijn.

Mijn team en ik hebben een eerste versie van een op EMA gebaseerd meetinstrument ontwikkeld om het dagelijks leven van ouderen met dementie die in verschillende zorgomgevingen wonen te meten, zoals reguliere verpleeghuizen, kleinschalige woonvormen of een zorgboerderij. ${ }^{43}$ Deze methodiek is vertaald naar het Noors, Engels en Duits en diverse onderzoekers gebruiken de methode om meer inzicht te krijgen in de omgeving en het gedrag. Ik wil het instrument verfijnen en mogelijkheden exploreren om ook nieuwe manieren met behulp van technologie toe te voegen Bijvoorbeeld via sensoren, wearables of andere data die via technologische middelen verzameld kunnen worden in het dagelijks leven. Via de samenwerking met het Joint Artificial Intelligence Network (JAIN), werk ik hierin samen met onderzoekers uit zowel de Artificial Intelligence (Al) kant als de zorgwetenschappen

Dit brengt mij bij het laatste onderdeel van mijn rede, wat ga ik de komende jaren doen?
"Het is belangrijk ervaringen en

gedrag van personen te meten op het moment dat ze ook daadwerkelijk plaatsvinden: real-time, zonder vertraging, in hun natuurlijke context en situatie, over de tijd heen" 


\section{De leerstoel}

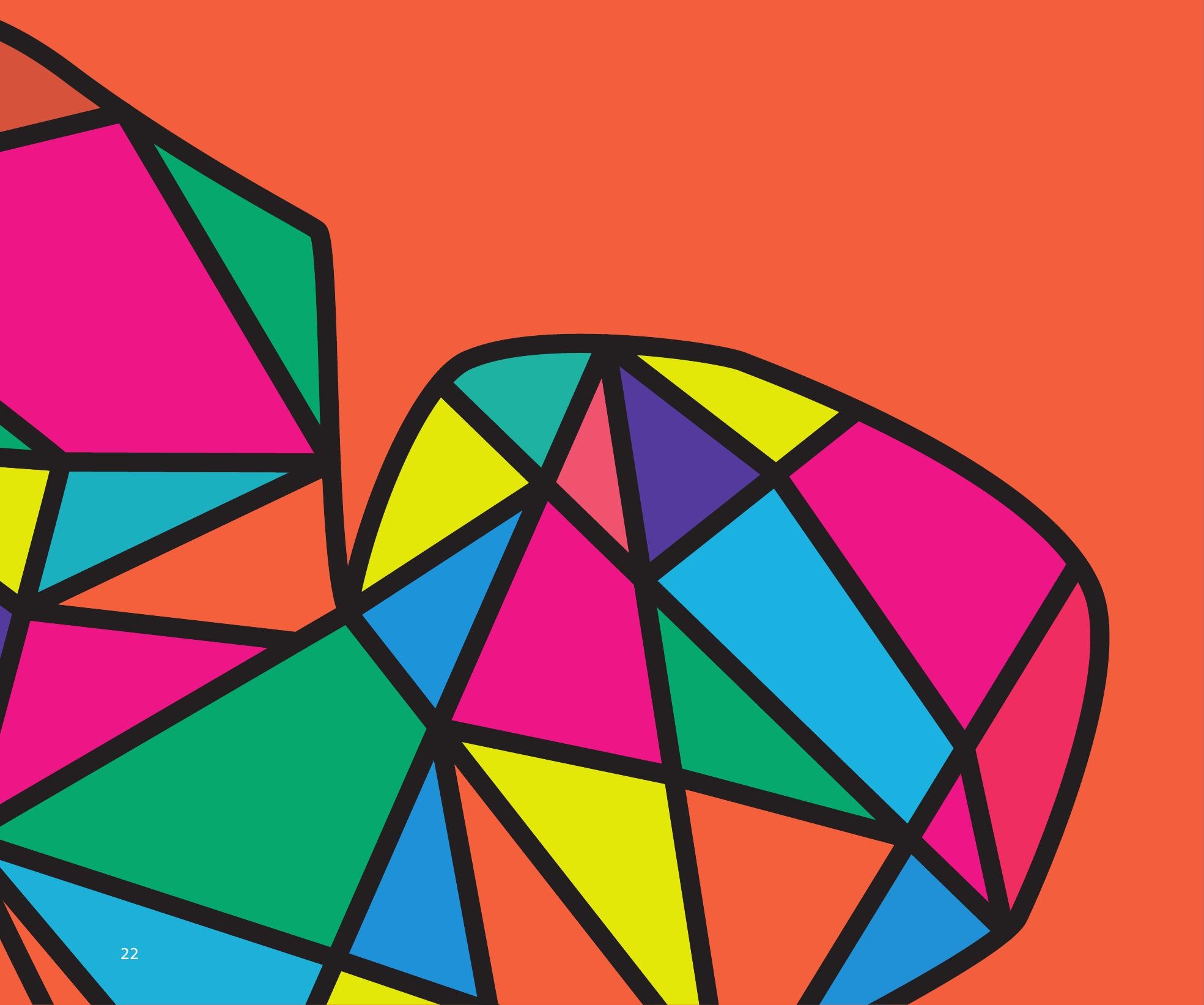

Mijn hart ligt bij de wetenschap: vragen stellen bij concepten in ons denken en zoeken naar verbanden en nieuwe concepten, waarbij bewijsvoering, creativiteit en een kritische houding noodzakelijk zijn. Wetenschap beoefen je nooit alleen, en hoewe individuen een belangrijke rol kunnen spelen, ontwikkelt kennis zich in een gemeenschap.

Mijn leerstoel is gevestigd binnen de Academische Werkplaats Ouderenzorg Limburg een structuree en interdisciplinair samenwerkingsverband tussen negen grote zorgorganisaties, het mbo, hbo en wo in Limburg. Ik werk aan het vormen van zo'n gemeenschap in de langdurige ouderenzorg, niet alleen met wetenschappers maar juist ook vanuit een actieve verbinding met de maatschappij. .k betrek ouderen en hun naasten, professionals, bestuurders, docenten, zorgverzekeraars, ondernemers, studenten, beleidsmakers, gemeenten, architecten en woningbouwcorporaties bij kennisontwikkeling en het delen van kennis.

Dit wordt ook wel transdisciplinair onderzoek genoemd. ${ }^{45}$ Dit gaat uit van samenwerking tussen wetenschappelijke en maatschappelijke partijen om complexe en urgente vraagstukken op te lossen.

Vaak wordt gesproken over wetenschap en maatschappij alsof ze losstaande entiteiten zijn.
Twee werelden die niet met elkaar verbonden zijn. Ik zie dat anders; wetenschap is onderdee van de maatschappij. Wetenschappelijke en maatschappelijke invloed van onderzoek ontstaan vanuit de interactie die je hebt als onderzoeker in het gehele ecosysteem: allerlei verschillende actoren werken hierbij samen om kennis te ontwikkelen en te gebruiken. ${ }^{46}$ Het lineaire beeld dat nog bestaat waarin wetenschappers kennis ontwikkelen die

“Wetenschap beoefen je nooit

alleen, en hoewel individuen

een belangrijke rol kunnen

spelen, ontwikkelt kennis zich

in een gemeenschap."

een ander, bijvoorbeeld de maatschappij, gebruikt, vind ik achterhaald. Ik zet me dan ook graag binnen de Universiteit Maastricht en vanuit De Jonge Akademie in, om ook de wetenschappelijke wereld in beweging te brengen. Om wetenschap anders te Erkennen en Waarderen en zo mede vorm te geven 
aan de citizen science beweging. ${ }^{47}$ Universiteiten zijn maatschappelijk betrokken en spelen een actieve en verbindende rol in het oplossen van vraagstukken dicht bij huis. Dit kan er voor iedere universiteit anders uitzien, afhankelijk van de lokale context. In de grensstreek en krimpregio Limburg, en in het bijzonder Zuid-Limburg, waar mijn leerstoel gepositioneerd is, ligt er een heel duidelijk vraagstuk in de ouderenzorg, omdat de bevolking sterk vergrijst en het voorzieningenniveau terugloopt.

Met wetenschap wil ik bijdragen aan het verbeteren van het dagelijks leven en functioneren van ouderen en hun naasten. En hierbij juist uitgaan van wat ouderen nog wel kunnen, hun restcapaciteit gebruiken, hoe we positieve uitkomsten kunnen behouden en meer mogelijk maken. Dit vraagt om een interdisciplinaire insteek, waarbij ik inzichten combineer vanuit hoe men een omgeving ervaart (met name onderzocht vanuit de gerontologie, antropologie en sociale ecologie), hoe de omgeving wordt gebruikt (vanuit de geriatrie, verplegingswetenschap en psychologie), hoe de omgeving is ontworpen (architectuur) en hoe zorg- en dienstverlening zijn georganiseerd (organisatiewetenschappen en strategisch management). Door de kracht van verbinding tussen vakgebieden en disciplines kun je samen iets nieuws

\section{creëren wat je alleen niet zou kunnen.}

Ik ben me ervan bewust dat het lastig kan zijn om over de grenzen van je eigen perspectief heen te kijken in wetenschappelijk onderzoek met verschillende stakeholders. Je spreekt elkaars taal niet, wat kan zorgen voor wrijving. In de drukte van alledag moet je uit je comfortzone komen, jezelf openstellen voor een ander en bewust over de muu van je eigen perspectief heen kijken: wat bedoelt diegene en waarom?

Concreet richt ik me op drie pijlers:

1 wetenschappelijk onderzoek

2 onderwijs;

3 verdere academisering van de langdurige ouderenzorg.

\section{Onderzoek}

Innovatieve vormen van wonen met zorg bieden veel kansen voor wetenschappelijk onderzoek naa de werkingsmechanismen van de zorgomgeving. De zorgomgeving kan gezien worden als complexe interventie. Dit betekent dat er:

a een groot aantal componenten is dat met elkaar interacteert; b dat de zorgomgeving invloed heeft op gedrag van verschillende doelgroepen, zoals bewoners, hun familie en medewerkers, en op verschillende niveaus in een organisatie;

c dat er vele verschillende uitkomsten zijn die de zorgomgeving beïnvloeden en

d dat er een bepaalde mate van flexibiliteit en aanpassing nodig is tijdens de toepassing van de componenten. ${ }^{48}$

Ik wil met mijn onderzoek nieuwe kennis ontwikkelen om de mechanismen te ontrafelen hoe de zorgomgeving het dagelijks leven en functionere van ouderen beïnvloed.

Ten eerste met nieuw onderzoek naar zorghoeves en vergelijkbare boerderijconcepten, omdat zij ee unieke uitgangssituatie bieden met een fysieke, sociale èn organisatorische omgeving die op elkaa zijn afgestemd, met als doel een betekenisvol en actief dagelijks leven te stimuleren. Katharina Rosteius is dit jaar gestart met haar promotieonderzoek op dit onderwerp. Momenteel woont zij een aantal dagen in de week op 't Zorgerf te Putten, waar zij de werkingsmechanismen in de zorgomgeving onderzoekt. Deze willen we vertalen naar nieuwe manieren van wonen en werken, welke in praktijk gebracht worden in De Hoeve, een nieuwe locatie van MeanderGroep Zuid-Limburg. Ook de bredere maatschappelijke betekenis die een woonzorgvoorziening kan hebben op de lokale gemeenschap nemen we mee. Daarnaast willen we dit onderzoek ook verbreden naar andere concepten en de effecten in het dagelijks leven over langere tijd meten.

Ten tweede wil ik met mijn onderzoek nieuwe kennis ontwikkelen via onderzoek naar transities, veranderingen van omgeving. Wat doet bijvoorbeeld een verhuizing naar een innovatief woonzorgconcept met bewoners en hun naasten en medewerkers? ledere verhuizing is enorm ingrijpend voor verpleeghuisbewoners met hun complexe zorgvraag en hun naasten. Het veranderen van omgeving vraagt grote aanpassingen. Ik heb een grootschalige studie opgezet naar de impact van verhuizingen binnen de verpleeghuiszorg en hoe deze verbeterd kunnen worden, vanuit het landelijke consortium met de vijf andere academische netwerken ouderenzorg, uit Amsterdam, Leiden, Nijmegen, Tilburg en Groningen: de RELOCAREstudie. Mara Brouwers onderzoekt de gevolgen en ervaringen van verhuizing naar innovatieve woonzorgconcepten als alternatief voor het traditionele verpleeghuis op ouderen en hun naasten. 
Ouderen maken veel transities door in de langdurige zorg: van thuis naar het ziekenhuis, revalidatie of verpleeghuis. Zijn al deze transities wel noodzakelijk, kunnen we ze voorkomen en als ze dan nodig zijn, hoe kunnen we deze zo goed mogelijk laten verlopen? Dit zijn de centrale vragen in het TRANS SENIOR consortium, een samenwerking tussen zeven Europese landen, waarin we dertien jonge onderzoekers opleiden tot de zorginnovatoren van de toekomst. Zij volgen hun promotietraject aan twee verschillende universiteiten. Zes van deze onderzoekers doen hun onderzoek aan de Universiteit Maastricht, van wie ik er vijf mag begeleiden: Lindsay Groenvynck, Amal Fakha en nes Mouchaers hebben Maastricht als standplaats; Merel Leithaus en Megan Davies doen hun onderzoek in Maastricht met Universiteit Maastricht als tweede universiteit.

Ten derde wil ik via mijn onderzoek meer inzich krijgen in de invloed van de organisatiecultuur op het dagelijks leven, met als aandachtspunten leiderschap, teamcultuur, en het creëren van een open leer-en verbeterklimaat. Cultuur vormt de gedachten, aannames, visie en waarden die medewerkers hebben en onderliggend zijn aan het gedrag om de zorg- en dienstverlening te realiseren. Hoe kunnen we meer relatiegerichte zorg verlenen samen met ouderen, hun naasten èn medewerkers Samen met Ramona Backhaus en Johanna Rutten onderzoek ik hoe teams in verpleeghuizen samen met bewoners en hun naasten leren en verbeteren om zorg nog beter af te kunnen stemmen op de wensen en behoeften van bewoners. Met Elke Prumpeler en Petra Erkens maken we de vertaalslag naar de beroepsgroep met onderwijskundige expertise vanuit het mbo en hbo. De manier waarop zorgverleners handelen en het gedrag dat zij vertonen, beïnvloedt mede het functioneren van kwetsbare ouderen. Mensen met dementie bijvoorbeeld, kunnen niet altijd zelf initiatief meer nemen, maar reageren wel op uitnodiging en stimulans vanuit hun sociale omgeving. Andersom komt ook voor: wanneer mensen wel initiatief nemen maar wij als zorgverlener hier dilemma's zien omdat het wellicht de veiligheid van mensen in het gedrang brengt.

Dit kan leiden tot vrijheidsbeperking en onvrijwillige zorg: zorg waartegen mensen zich verzetten en/ of die zonder hun toestemming plaatsvindt. Samen met Michel Bleijlevens onderzoek ik hoe we medewerkers en mantelzorgers beter kunnen ondersteunen bij deze complexe vraagstukken thuis, waar dilemma's rondom vrijheid en veiligheid van ouderen aan de orde van de dag zijn. Angela
Mengelers is onlangs gepromoveerd om onvrijwillige zorg te voorkomen en Vincent Moermans zet het onderzoek voort, in samenwerking met onze Vlaamse collega's van het Wit-Gele Kruis.

Om bovengenoemde impact en effecten van de zorgomgeving vast te kunnen stellen, werk ik aan betrouwbare en valide meetinstrumenten met hierin centraal het perspectief van oudere en hun naasten. Ik pas principes van Ecological Momentary Assessments (EMA) toe in de (door) ontwikkeling van meetinstrumenten. Dit betekent dat we gedrag en functioneren herhaaldelijk meten in interactie met de context waarin personen zich bevinden. Hierdoor kan het samenspel tussen ervaringen, gedrag en aspecten van de omgeving inzichtelijk gemaakt worden, zoals in de Maastricht Electronic Daily Life Observation-tool die we hebben ontwikkeld. ${ }^{43}$ Daarnaast werk ik samen met mijn collega Sil Aarts om datascience technieken in te zetten voor de grote hoeveelheden data die reeds verzameld worden in het dagelijkse zorgproces. Coen Hacking onderzoekt in dit kader de mogelijkheden van tekstmining om meer inzicht te krijgen in de ervaren kwaliteit van ouderenzorg. Met Katya Sion, onlangs gepromoveerd, heb ik een narratieve methodiek ontwikkeld om de kwaliteit vanuit het perspectief van ouderen te meten, rekening houdend met de dynamiek in relaties: de Ruimte voor Zorg-methodiek. ${ }^{49,50}$ Momenteel werken we aan de doorontwikkeling en brede verspreiding in de ouderenzorg van deze methode.

\section{Onderwijs}

Wetenschappelijk onderzoek en onderwijs gaan hand in hand. Nieuwe kennis en inzichten dragen bij aan het verbeteren van de kwaliteit van onderwijs en de professionele ontwikkeling van studenten en medewerkers in de ouderenzorg. Met de leerstoel wil ik bijdragen aan nieuwe, inspirerende en doeltreffende manieren van leren. $\mathrm{lk}$ wil $\mathrm{me}$ inzetten om jongeren écht anders en met nieuwe, wetenschappelijk onderbouwde kennis te kunnen opleiden voor de ouderenzorg. Dit wil ik doen doo me zowel op de huidige en toekomstige studenten te richten alsook op de medewerkers die al werke in de ouderenzorg.

Ik beoog kennis uit mijn wetenschappelijk onderzoek te verwerken in de curricula op mbo en hbo en wo, om zo de huidige en toekomstige studenten kennis te laten maken met de ouderenzorg. Voorbeelden hiervan liggen in de opleiding gezondheidswetenschappen waarin ik het principe van een flipped classroom toepas, ontwikkeld samen met Nynke de Jong. Dit keert de 
traditionele leeromgeving om door studenten vooraf online colleges aan te bieden over de theorie achter woonzorgomgevingen. Vervolgens gaan ze in het klaslokaal casuïstiek bespreken uit de dagelijkse praktijk, onder begeleiding van de docent, over wat de beste plek is om te wonen voor mevrouw Jansen. Mevrouw Jansen is een oudere dame met dementie en heeft complexe problematiek. Studenten maken groepjes vanuit de rol als ouderen en hun naasten zorgprofessional, financier en beleidsmaker en gaan met elkaar in discussie over passende oplossingen.

Verreweg het grootste deel van de medewerkers in de ouderenzorg heeft een mbo-achtergrond. Het is daarom van groot belang dat opleidingen hun studenten voorbereiden op de toekomst, met vaardigheden als creativiteit en flexibiliteit en het intregreren van zorgtaken in het dagelijks leven. De veranderende verwachtingen aan zorgmedewerkers vragen om een andere rol van docenten en praktijkbegeleiders. Samen met het Gilde Zorgcollege zijn we een pilot evaluatie van ee nieuw hybride leer- en werktraject "Met éen been in de maatschappelijke zorgpraktijk" gestart. Op locatie kregen studenten les in de theorie en achtergrond van bijvoorbeeld dementie. Daarna gingen de studenten in de praktijk naar de bewoners, negen op een zorgboerderij en negen in een gewoon verpleeghuis. Hier konden ze direct het geleerde toepassen in de praktijk en ontstonden direct allerlei leervragen bij de studenten. Hoe communiceer je eigenlijk met mensen met dementie? Hoe overkom ik mijn aanvankelijke angst? Als ik een vraag stel en een bewoner antwoordt niet, wat doe ik dan? Omdat de docent aanwezig was in de zorgpraktijk kon dit meteen met de student besproken worden Docenten deden hierdoor gedwongen een stapje terug. Dingen waarvan ze aannamen dat studenten ze kenden, bleken toch niet uit de verf te komen. Zo konden ze studenten direct en in het moment coachen op leervragen die voor de studenten relevant en belangrijk waren. De praktijkbegeleiders kwamen zo ook weer op de hoogte van de meest recente inzichten uit de theorie.

Wanneer wetenschap, onderwijs en praktijk de krachten bundelen, creëren we zo mogelijk een gouden formule voor de uitdagingen van de toekomst. Dit zien we ook in de duale opleiding HBO-Verpleegkunde, richting Ouderenzorg. Opgezet vanuit Zuyd Hogeschool, leiden docenten, samen met medewerkers uit de praktijk en onderzoekers, HBO studenten op tot verpleegkundigen. Zij werken bij één zorgorganisatie, maar volgen hu opleiding roulerend bij andere zorgorganisaties, waarbij het hele palet aan ouderenzorg voorbijkomt: van thuiszorg, wijkgerichte zorg, revalidatie, palliatieve zorg en verpleeghuiszorg. Innovaties, en wetenschappelijk onderzoek op deze thema's liggen ten grondslag aan de opleiding, die verpleegkundigen opleidt tot vakinhoudelijke leiders. Bovendien ben ik erg blij dat sinds twee jaar de opleiding tot Specialist Ouderengeneeskunde gegeven wordt vanuit de Universiteit Maastricht. Ook daar lever ik graag een bijdrage aan.

Academisering ouderenzorg

Wetenschappelijk onderzoek is van grote waarde in de ouderenzorg. Om meer kennis te ontwikkelen over wat er wel en niet werkt om ouderen en hun naasten te ondersteunen in het dagelijks leven. Maar juist ook als een belangrijk middel om medewerkers in de ouderenzorg te stimuleren om verder te denken dan hun eigen praktijk hun huidige manier van zorgverlening. I wil het onderzoekend leren in de praktijk stimuleren. Door meer professionals te betrekken bij onderzoek vanu diverse rollen, stimuleren om zelf actief kennis te ontwikkelen door vragen te stellen, onderzoek te doen en zo tot oplossingen te komen. Dit is voor iedereen toepasbaar, van huishoudelijke hulp tot de specialist ouderengeneeskunde, van verzorgende to bestuurder.
Wetenschappelijk onderzoek creëert een onafhankelijke ruimte, virtueel of fysiek, waarin mensen met verschillende achtergronden, opvattingen en denkbeelden, elkaar kunnen ontmoeten en elkaars ideeën op een veilige manie kritisch kunnen bediscussiëren. Wanneer je als medewerker in de ouderenzorg mee kunt doen aan wetenschappelijk onderzoek, raak je in gesprek met een ander. Met allerlei verschillende visies, manieren van handelen en ideeën over hoe goede zorg eruitziet in de praktijk. Je kunt vragen formuleren die je raken, omdat je ze ziet in de dagelijkse praktijk.

Je kunt meedenken over wat resultaten nu eigenlijk betekenen, onderzoekers helpen om bevindingen te duiden: hoe komt het dat je iets vindt? Juist als je resultaten vindt die je niet verwacht. Zo vonden we in een studie dat in een bepaald huis bewoners helemaal niet zoveel bewogen en erg veel zaten. Terwijl het beeld omgekeerd was: in dit huis was er juist veel ruimte voor beweging. Tijdens het gesprek waarin de onderzoeker de bevindingen terugkoppelde kwam een mooi gesprek op gang tussen de verschillende medewerkers: is het zo dat alle bewoners profiteren of zijn het altijj dezelfden die je ziet? En op de afdelingen zelf was het merendeel inderdaad erg inactief en werd daar weinig aandacht aan besteed. Dit opende ogen. 
Met wetenschappelijk onderzoek kun je een kritische houding stimuleren ten aanzien van de informatie die je krijgt; ten aanzien van je werk. En dit geldt niet alleen in de zorg maar juist ook in de wetenschap. Ik wil bijdragen aan het trainen van onderzoekers om ook echt samen met de praktijk je onderzoek vorm te geven, om je uit te laten dagen over de theorieën en hoe deze tot uiting komen in de praktijk. Zodat we als onderzoekers zowel bijdragen aan de theorievorming en kennisontwikkeling in de wetenschap als aan het ondersteunen van evidencebased werkwijzen in de langdurige ouderenzorg.

Onze Academische Werkplaats Ouderenzorg Limburg is een uniek construct dat al bijna 25 jaar de positieve invloeden laat zien van interdisciplinaire en structurele samenwerking tussen wetenschap, praktijk en onderwijs. ${ }^{51}$ Binnen MeanderGroep is Silke Metzelthin de wetenschappelijke linking pin met wie ik hierin samenwerk.

Graag wil ik nog meer ambassadeurs mobiliseren in de zorg- en onderwijsorganisaties. Dat kunnen zorgmedewerkers zijn, maar ook

vertegenwoordigers van cliënten, beleidsmakers en docenten. Enthousiaste mensen die geïnteresseerd zijn in wetenschap. Hen een uitdaging bieden en mogelijkheden voor een leven lang leren. En een aantrekkelijke leer- en werkomgeving bieden om jongeren te enthousiasmeren om voor de langdurige ouderenzorg te kiezen en daar te blijven.

Zij zijn enthousiast over de programma's en de inhoud van het onderzoek: ze hebben het zelf mee bedacht en kunnen er ook zelf in hun eigen praktijk vorm aan geven. Maar dit vasthouden, ondanks de waan van alledag, blijft een uitdaging. Ik zet me graag in om hen te hierin te versterken. 


\section{Afsluiting}

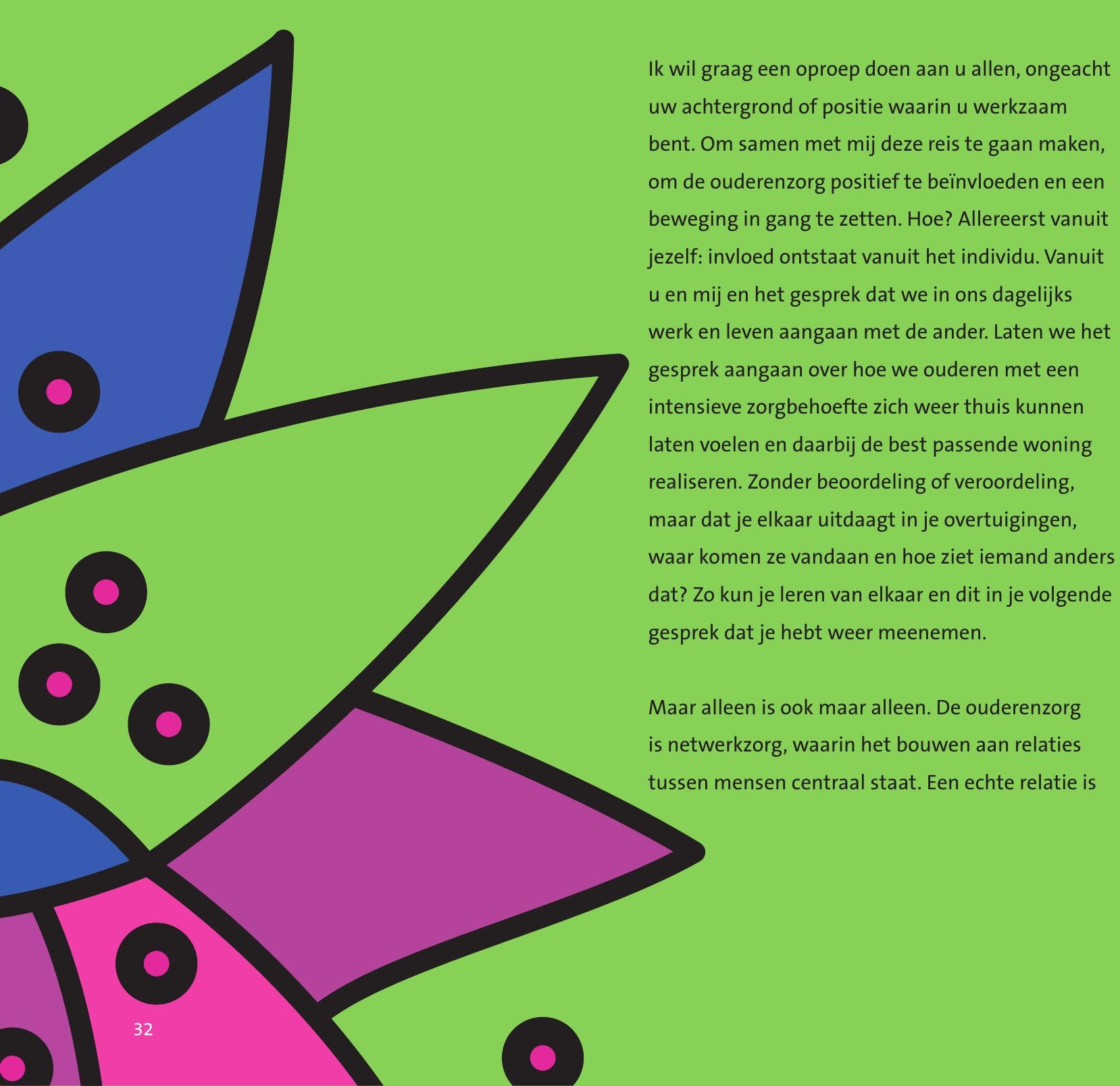

wederkerig: ik kan iets voor jou betekenen en jij voor mij, we worden samen beter; daarom werkt het partnerschap. Laten we sterker inzetten op die wederkerigheid, omdat alleen de inzet, kennis en ervaring van ons allen genoeg is voor de gewenste resultaten en verandering in de langdurige

ouderenzorg.

Om uiteindelijk blijvende invloed te realiseren heb je ook de organisatie nodig: universiteiten, zorgen welzijnsorganisaties, onderwijsinstellingen,

verzekeraars, gemeente of woningbouw om er maar een aantal te noemen. De individuele ervaring wordt gevormd door het beleid van de organisatie. We hebben de bestuurders nodig, managers en leiders om ons te helpen zaken te realiseren. Om slagkracht te hebben in de organisatie en bestaande structuren te veranderen.

Om aan deze oproep te beantwoorden is vertrouwen nodig, creativiteit om je buiten gebaande paden te begeven en initiatief. Gewoon doen en kijken waar je uitkomt. En wellicht mislukt er iets, falen we in dat wat we beogen. Raken we gaandeweg boos, verdrietig of gefrustreerd omdat de ander ons niet begrijpt, omdat het niet lukt wat je voor ogen had of gewoon zomaar. In de wetenschap is falen nodig om tot goede theorievorming te komen. Laten we elkaa in de praktijk ook wat vaker het experiment gunnen.

Ik wil graag afsluiten met de Deense filosoof Kierkegaard, die zei "Durven is je evenwicht verliezen". Mensen die mij persoonlijk kennen, weten dat dit citaat op mij betrekking heeft, niet alleen figuurlijk maar ook letterlijk. Ik val nogal vaak. Bij Kierkegaard komt erachteraan: "Niet durven is jezelf verliezen". Laten we onszelf niet verliezen, en iedere dag weer opnieuw durven. En gezamenlijk een omgeving creëren die je opvangt als het nodig is.

"Durven is je evenwicht verliezen. Niet durven is jezelf verliezen"

Kierkegaard 
Dankwoord

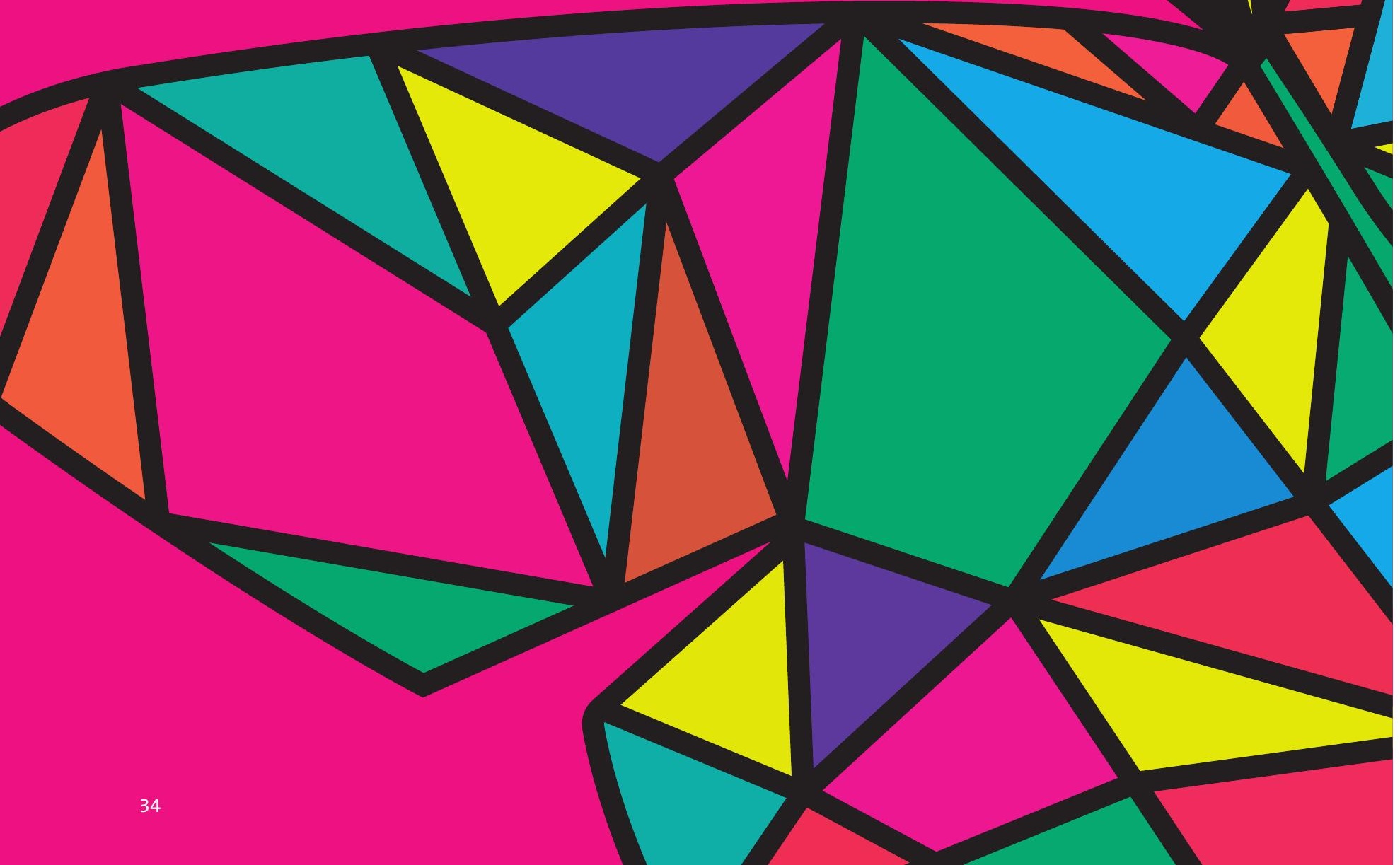

Zoals ik eerder zei, wetenschap beoefen je nooit alleen. Ik kan iedereen niet genoeg bedanken die mijn pad tot nu toe mede mogelijk heeft gemaakt.

Het College van Bestuur van de Universiteit Maastricht, het bestuur van de Faculty of Health, Medicine and Life Sciences en de Raad van Bestuur van MeanderGroep Zuid Limburg dank ik voor het in mij gestelde vertrouwen. Een aantal personen wil ik daarbij met naam noemen, te weten prof. dr. Rianne Letschert, Rector Magnificus van de UM, prof. dr. Annemie Schols, decaan, en prof. dr. Nanne de Vries, vice-decaan van de Faculteit en Jack Jansen, voorzitter Raad van Bestuur van Meandergroep Zuid Limburg.

Ik voel me gezegend dat ik verschillende plekken heb waar ik mezelf thuis voel, zowel op het werk als daarbuiten.

Alle collega's en mensen betrokken bij de Academische Werkplaats Ouderenzorg Limburg. Dit zijn de linking pins, onderzoekers, alle medewerkers actief in de ouderenzorg, cliëntvertegenwoordigers, ouderen en hun naasten, docenten, beleidsmakers en bestuurders. Dank voor alle inspiratie,

motiverende gesprekken en het vertrouwen om samen wetenschappelijk onderzoek in de ouderenzorg te versterken. In het bijzonder wil ik de leden van de Commissie Zorgonderzoek van MeanderGroep noemen en alle overige medewerkers en cliëntvertegenwoordigers die de verschillende onderzoeksprojecten mede mogelijk maken.

Precies 10 jaar geleden verdedigde ik mijn proefschrift en tijdens dat traject is mijn ambitie voor wetenschappelijk onderzoek geboren.

Prof. dr. Jan Hamers, mijn eerste promotor en programmaleider van ons onderzoeksprogramma Ageing and Long-Term Care. Jouw betrokkenheid, motiverende houding en brede blik op onderzoek en praktijk zijn voor mij onmisbaar geweest. Ik ben je zeer erkentelijk dat ik de kans heb gekregen me verder te ontwikkelen als wetenschapper. Bovendien stond jij aan de wieg van de werkplaats in 1998, samen met een verpleeghuis dat momenteel onderdeel is van de MeanderGroep. Het is voor mij een bijzondere eer om vandaag mijn leerstoel, mogelijk gemaakt door diezelfde organisatie, te mogen aanvaarden.

Prof. dr. Ruud Kempen, mijn tweede promotor. Jouw deskundigheid, zorgvuldigheid en positief kritische blik hebben mij altijd ontzettend gescherpt. Samen 
met Jan Hamers heb je het programma Ageing and Long-Term Care opgezet met veel oog voor teamwetenschap en ik doe mijn best, in mijn rol als mede-programmaleider, om dat gedachtegoed voort te zetten.

Prof. dr. Sandra Zwakhalen, begonnen als kamergenoten bij mijn start als jonge promovenda bij destijds Zorgwetenschappen. Ik heb veel van je mogen leren op onderzoeksgebied, als sparringpartner en collega. Jouw rust en kalmte waardeer ik zeer. Twee jaar geleden ben je me voorgegaan met je benoeming tot hoogleraa Verplegingswetenschap en ik zie ernaar uit om onze mooie plannen tot uiting te laten komen.

Dr. Erik van Rossum, als dagelijks begeleider en co-promotor van het eerste uur heb je me wegwijs gemaakt in de wereld van de wetenschap Ontzettend veel dank daarvoor. Inmiddels

kamergenoot geworden; mijn excuses voor de chaos op mijn bureau. Herinner mijn stelling van destijds "If a cluttered desk is a sign of a cluttered mind, of what, then, is an empty desk a sign?"

Mijn standplaats is bij de vakgroep Health Service Research, onder leiding van vakgroepvoorzitter prof. dr. Dirk Ruwaard. Een vakgroep met collega's uit allerlei disciplines, van onderwijswetenschap to management en zorggerelateerde disciplines. Daar komen altijd interessante gesprekken uit voort bij de koffieautomaat. Bernike, Joanna en Brigitte ben ik veel dank verschuldigd voor alle ondersteuning.

Een speciaal woord van dank gaat uit naar alle promovendi en onderzoekers die ik mag begeleiden. Ik geniet van de groei en ontwikkeling die jullie doormaken, van de enthousiaste discussies die we voeren en waardeer de accuratesse en zorgvuldigheid die jullie leggen in de dataverzameling en analyses.

Ik ben erg blij met alle samenwerkingspartners in het onderzoek, teveel om allemaal bij naam te noemen. Toch een speciaal woord van dank aan mijn collega's van de andere academisch netwerken ouderenzorg, in het bijzonder prof. dr Raymond Koopmans, prof. dr. Debby Gerritsen, prof. r. Wilco Achterberg, prof. dr. Cees Hertogh, prof. dr. Bianca Buurman, prof. dr. Katrien Luijkx, prof. dr. Sytse Zuidema en hun vele collega's. Ik vind het fantastisch dat we ons eerste gezamenlijke project gestart zijn: het onderzoek naar verhuizingen in de verpleeghuiszorg.
I would like to thank my international collaborators. The Interdem network, a pan-Eurpean Network of researchers collaborating in research and dissemination of Early, Timely and Quality Psychosocial Interventions in Dementia and the International Psychogeriatric Association, of whic I am on the Board of Directors. I am proud that we have set up a network for Early Stage Caree researchers and professionals to encourage them in their work on old age mental health.

Mijn collega's van De Jonge Akademie wil ik

bedanken voor alle energie, inspirerende gesprekken en fijne samenwerkingsprojecten, om zo ook het wetenschappelijke veld te bewegen, zoals in het traject omtrent Erkennen en Waarderen, en het belang van wetenschap uit te dragen.

En dan mijn persoonlijke zorgomgeving. Al mijn lieve familie en vrienden, dank voor alles. Jullie zijn mijn steun en toeverlaat, mijn vangnet als ik val en samen beleven we ontzettend veel plezier. Mijn schoonouders, Netty en Bernard, een rots in de branding en altijd klaar voor ons en de kindjes.
Lieve pap en mam, dank voor alle goeie zorgen. Door jullie betreed ik de wereld met een open blik en vol vertrouwen, kan ik relativeren, doorzetten, en heb ik geleerd nooit op te geven. Ook ben ik trots op hoe jullie, inmiddels beiden 76 , de afgelopen jaren hebben geleerd en nieuwe ervaringen hebben opgedaan die jullie nooit voor mogelijk hadden gehouden; en dat op latere leeftijd.

Allerliefste Wout en Thomas, wat voel ik me gezegend jullie moeder te mogen zijn. Jullie zijn nog te klein om hier naar mij in deze rare jurk (jullie woorden) te luisteren. Volgens Wipneus en Pim is een professor iemand die, en ik citeer, "...geweldig knap is. Niet zo'n klein beetje knap. Nee, werkelijk héé héél erg knap." 52 Dus de lat ligt hoog om hieraan te voldoen zeg maar...Gelukkig weet ik alles van pinguïn-dansen en kanaries en kom ik daar in de dierentuin nog een heel eind mee.

Lieve Fred. Mede door jou sta ik hier. Je geeft me kracht met je vertrouwen, onvoorwaardelijke steun en geloof in mij en ons. We bewandelen ieder tevens onze eigen paden en zijn toch altijd samen. Jij bent mijn thuis.

Ik heb gezegd. 


\section{Referenties}

is

.

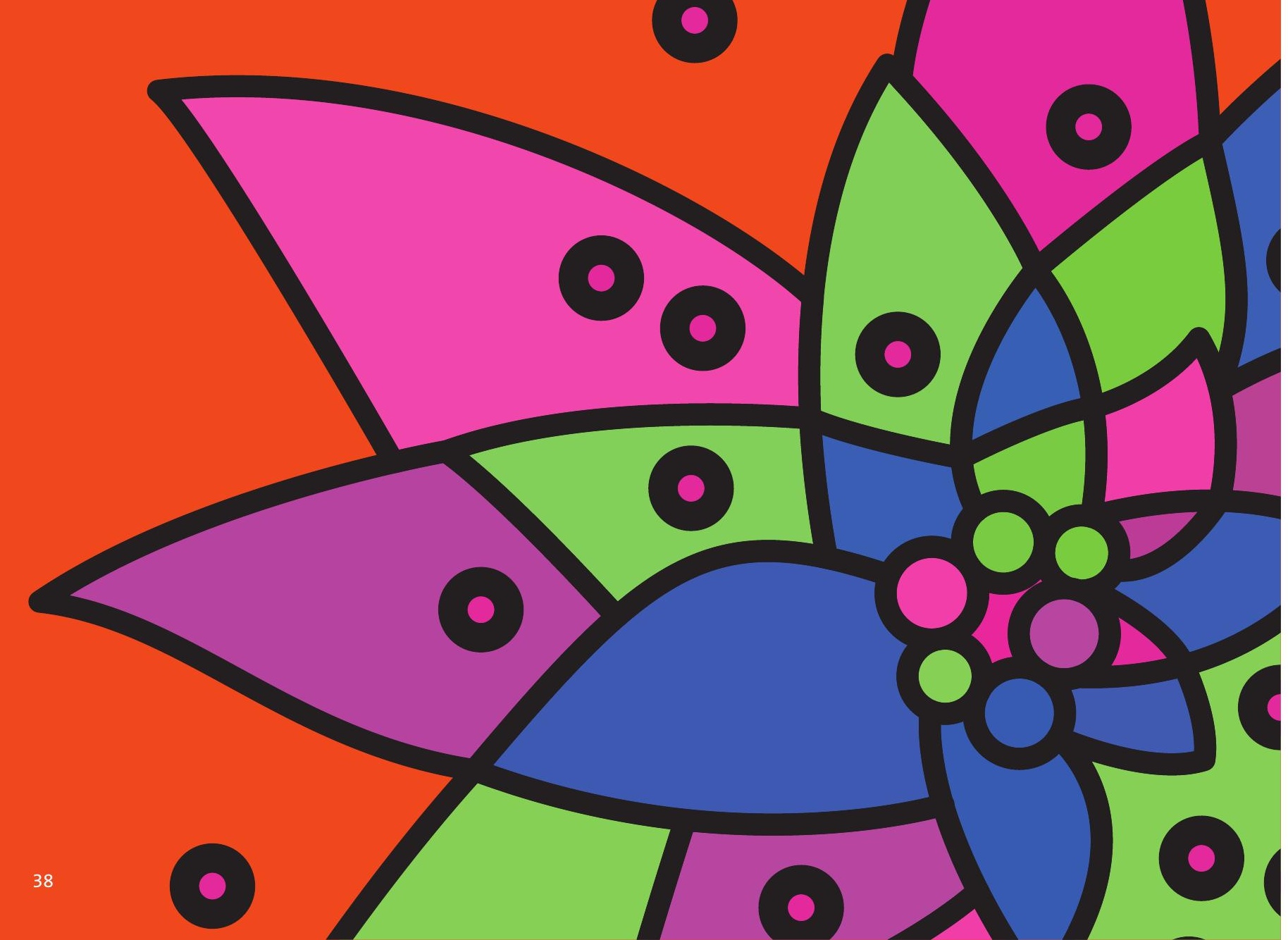

Lawton MP, Nahemow L: Ecology and the Aging Process. 1973

De Boer B, Bozdemir B, Jansen J., Hermans M, Hamers JPH, Verbeek H: The homestead: developing a conceptual framework through co-creation for Innovating Long-Term Dementia Care Environments. Int J Environ. Res. Public Health 2021, 18:57

3 Ministerie van Volksgezondheid, Welzijn en Sport: Magazine Programma Langer Thuis. Den Haag; November 2020

4 Rijnaard MD, van Hoof $\mathrm{f}$, Janssen BM et al: The Factors Influencing the Sense of Home in Nursing Homes: A Systematic Review from the Perspective of Residents. J Aging Res. 2016; 6143-645

5 Cater D, Tunalilar O, White DL, Hasworth S \& Winfree J: "Home is Home:" Exploring the Meaning of Home across Long-Term Care Settings.J J Aging Environment 2021 https://doi.org/10.1080/26892618.2021.1932012

6 Molony SL, Evans LK Jeon S Rabig $\mathrm{\&} \mathrm{Straka} \mathrm{LA:} \mathrm{Trajectories} \mathrm{of} \mathrm{at-} \mathrm{homeness} \mathrm{and} \mathrm{health} \mathrm{in} \mathrm{usual} \mathrm{care} \mathrm{and} \mathrm{small} \mathrm{house} \mathrm{nursing} \mathrm{homes}$ Gerontologist. 2011; 51(4), 504-515

7 Jong P, Rouwendal J, Hattum P, Brouwer A: Housing Preferences of an Ageing Population: Investigation in the Diversity Among Dutch Older Adults (July 16, 2012). Netspar Discussion Paper No. 07/2012-024, Available at SSRN: https://ssrn.com/abstract=2120458 or http://dx.doi.org/10.2139/ssrn.2120458

8 Filipovič Hrast $\mathrm{M}$, Sendi R, Kerbler B: Housing Choices of Older People: Staying or Moving in the Case of High Care Needs. Sustainability 2020, 12; 2888. https://doi.org/10.3390/su12072888

9 Costlow K, Parmelee PA, Choi SL, Roskos B. When Less is More: Downsizing, Sense of Place and Well-being in Late Life.J Environmental Psychology 2020101478

10 Filipovic Hrast M, Sendi R, Hebeec V, Kerbler B: Moving House and Housing Preferences in Older Age in Slovenia. Housing, Theory Society 2019; 36(1): 76-91

11 Blom J. Formal and Informal Long-Term Care in an Ageing Society. 2021. Rotterdam: Erasmus University

12 Beerens HC, Sutcliffe C, Renom-Guiteras A et al: Quality of Life and Quality of Care for People with Dementia Receiving Long-Term Institutional Care or Professional Home Care: The European RightTimePlaceCare Study.J Am Med Dir Assoc. 2014: 54-61

13 Grabowski DC. The Future of Long-Term Care requires investment in both facility-and home-based services. Nature Aging. 2021; 1, 10 11

14 Blackburg J, Locher J, Kilgore M. Comparison of Long-term Care in Nursing Homes Versus Home Health: Costs and Outcomes in Alabama. Gerontologist. 2016: 215-221

15 de Boer B, Hamers JP, Zwakhalen SM, Tan FE, Beerens HC, verbeek H: Green care farms as innovative nursing homes, promoting activities and social interaction for people with dementia. J Am Med Dir Assoc. 2017; 8(1):40-46 
16 den Ouden M, Bleijlevens MC, Meijers JMM et al: Daily (In)Activities of Nursing Home Residents in Their Wards: An Observation Study.J Am Med Dir Assoc 2015;16: 963-968

17 www.kenniscentrumsportenbewegen.n!

18 Sullivan GJ, Williams C. Older Adult Transitions into Long-Term Care: A Meta-Synthesis.J Gerontol Nurs. 2017;43(3):41-49. doi 10.3928/00989134-20161109-07.

19 den Ouden M, Kuk NO, Zwakhalen SMC, Bleijlevens MHC, Meijers JMM, Hamers JPH. The role of nursing staff in the activities of daily living of nursing home residents. Geriatr Nurs. 2017 May-Jun;38(3):225-230

20 Groenvynck L, Fakha A, de Boer B, Hamers JPH, van Achterberg T, van Rossum E, Verbeek H. Interventions to Improve the Transition from Home to a Nursing Home: A Scoping Review. Gerontologist. 2021 doi: 10.1093/geront/gnab036.

21 van Hoof $\mathrm{J}$, Verbeek $\mathrm{H}$, Janssen BM et al. A three perspective study of the sense of home of nursing home residents: the views of residents, care professionals and relatives. BMC Geriatr 2016; 16, 169 https://doi.org/10.1186/s12877-016-0344-9

22 van den Buuse S, de Boer A. Nieuwe woonvormen dringend nodig voor mensen met dementie. 2021 Alzheimer Nederland.

23 Verbeek $\mathrm{H}$, Tucker and $\mathrm{S}$, Wilberforce $\mathrm{M}$, Brand $\mathrm{C}$, Abendstern $\mathrm{M}$, Challis D. What makes extra care housing an appropriate setting for people with dementia? An exploration of staff decision-making. Dementia. 2019;18(5):1710-172

24 Chaudhury H, Cooke H, Cowie, H Razaghi L: The Influence of the Physical Environment on Residents with Dementia in Long-Term Care Settings: A Review of the Empirical Literature. Gerontologist 2017; 58: 325-37.

25 Marquardt G, Bueter K, Motzek T. Impact of the Design of the Built Environment on People with Dementia: An Evidence-Based Review. HERD: Health Environments Research \& Design Journal. 2014;8(1):127-157.

26 De Boer B, Beerens HCL, Katterbach MA, Viduka M, Willemse BM, Verbeek H. The physical environment of nursing homes for people with dementia: Traditional nursing homes, small-scale living facilities, and green care farms. Healthcare 2018, 6, 137.

27 Sion KY, Haex R, Verbeek Het al. Experienced Quality of Post-Acute and Long-Term Care From the Care Recipient's Perspective-A Conceptual Framework. 2019. J Am Med Dir Assoc; 20: 1386-1390

28 Hoek $\mathrm{U}$, van Haastregt IC, de Vries E, Backhaus R, Hamers JP, Verbeek H. Partnerships in nursing homes: How do family caregivers of residents with dementia perceive collaboration with staff? Dementia. 2021;20(5):1631-1648.

29 Verbeek H. Inclusion and support of family caregivers in nursing homes. In Dementia in nursing homes. Schüssler S, Lohrmann C. (eds.) 2017; Springer International Publishing.

30 Kemp CL, Ball MM, Perkins MM. Convoys of care: Theorizing intersections of formal and informal care. J Aging Stud. 2013; 27(1): 15-29
31 Vernooij-Dassen $M$, Leatherman $\mathrm{S}$, Olde Rikkert $M$. Quality of care in frail older people: the fragile balance between receiving and giving. BMJ 2011; 342:d403

32 Te Boekhorst S, Depla M, Pot A, De Lange J, \& Eefsting J. The ideals of group living homes for people with dementia: Do they practice what they preach? Int Psychogeriatr, 2011; 23(9), 1526-1527.

33 Verbeek H, Zwakhalen SMG, Van Rossum E, Kempen GIJM \& Hamers JPH. Small-scale, homelike facilities in dementia care: a proces evaluation into the experiences of family caregivers and nursing staff. 2012. Int J Nurs Stud; 49:21-29

34 Smit D, Willemse BM, de Lange J, Pot AM. Wellbeing-enhancing occupation and organizational and environmental contributors in lon term dementia care facilities: an explorative study. Int Psychogeriatr. 2014;26(1):69-80.

35 Teece DJ. Explicating dynamic capabilities: the nature and microfoundations of (sustainable) enterprise performance. Strategic Manag J. 2007; 28(13): $1319-1350$

36 Verbeek H, Peisah C, de Mendonca Lima, Rabheru, Ayalon. Human Rights to Inclusive Living and Care for Older People with Mental Health Conditions. Am J Ger Psych https://doi.org/10.1016/j.jagp.2021.05.023

37 Steele L, Swaffer K, Carr R, Phillipson L, Fleming R: Ending confinement and segregation: barriers to realising human rights in the everyday lives of people living with dementia in residential aged care, Austr J Human Rights, 2020;26:308-328

38 Ayalon L, Avidor S. 'We have become prisoners of our own age': from a continuing care retirement community to a total institution the midst of the COVID-19 outbreak, Age Ageing, 2021; afab013, https://doi.org/10.1093//geing/afab013

39 Beerens $\mathrm{HC}$, Zwakhalen SMC, Verbeek H et al. The relation between mood, activity, and interaction in long-term dementia care. Aging Ment. Health 2018, 22, 26-32.

40 de Boer B, Verbeek H, Zwakhalen SMG et al: Experiences of family caregivers in green care farms and other nursing home environments for people with dementia: a qualitative study. BMC Geriatr 2019;19: 149

41 de Boer B, Hamers JPH, Zwakhalen SMG, Tan FES, Verbeek H: Ouality of care and quality of life of people with dementia living at green care farms: a cross-sectional study. BMC Geriatrics. 2017; 17:155.

42 Cain AE, Depp CA, Jeste DJ. Ecological momentary assessment in aging research: A critical review. 2009. J Psychiatr Res, 43 (11);987-996

43 de Boer B, Beerens $\mathrm{HC}$, Zwakhalen SM, Tan FE, Hamers JP, Verbeek H. Daily lives of residents with dementia in nursing homes: development of the Maastricht electronic daily life observation tool. 2016. Int Psychogeriatr.28(8):1333-43

44 www.jainprojects.com

45 De Jonge Akademie. Grensverleggend: Kansen en Belemmeringen voor interdisciplinair onderzoek. Amsterdam 2015 
46 Smit J, Hessels LK. The Production of Scientific and Societal Value in Research Evaluation: A Review of Societal Impact Assessment Methods. Research Evaluation 2021. doi: 10.1093/reseval/rvab002

47 Nationaal Programma Open Science / werkgroep Citizen Science. Kennis en krachten gebundeld - citizen science in Nederland. 2020

48 Craig P, Dieppe P, Macintyre S. et al. Developing and Evaluating Complex Interventions: the new Medical Research Council Guidance. 2008. BMJ; 337:a1655

49 Sion KY, Verbeek H, Aarts S et al. The Validity of Connecting Conversations: A Narrative Method to Assess Experienced Quality of Care in Nursing Homes from the Resident's Perspective. Int J Environment Res Publ Health, 2020; 17(14):5100

50 Sion KY, Verbeek H, De Vries E et al. The Feasibility of Connecting Conversations: A Narrative Method to Assess Experienced Quality of Care in Nursing Homes from the Resident's Perspective. Int J Environment Res Publ Health, 2020; 17(14):5118

51 Verbeek H, Zwakhalen SMG, Schols JMGA, Kempen GIJM \& Hamers JPH. The living lab in ageing and long-term care: a sustainable model for translational research improving quality of life, quality of care and quality of work. 2020. J Nutr Health Aging 24(1):43-47

52 van Wijckmade B. Wipneus en Pim Bij Snuffelbaard. 2014. ImageBooks Factory, Veghel

De projecten waarnaar in de tekst gerefereerd wordt, zijn te vinden op de website van de Academische Werkplaats Ouderenzorg Limburg | www.awolimburg.nl

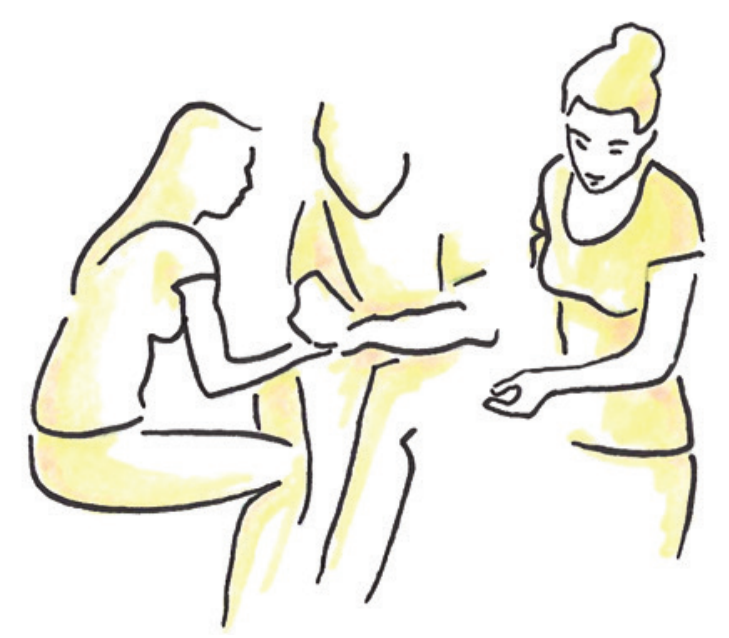




\section{"Van mij werd}

\section{nooit iets}

verwacht. Ik was

een meisje hè"

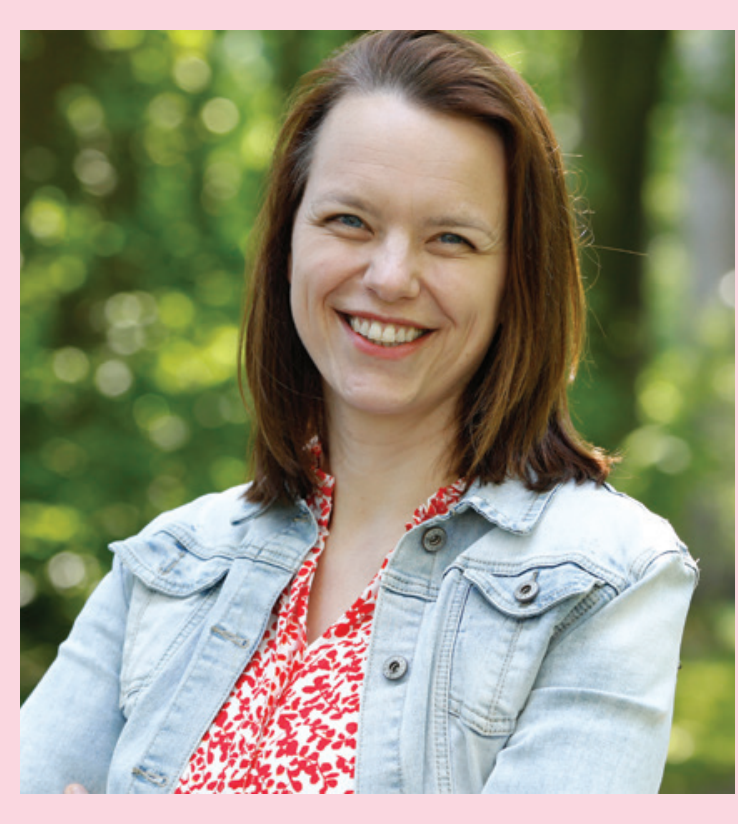

Werd ze van huis uit gestimuleerd om zo hoog mogelijk te mikken? Niet bepaald, nee. Omgekeerd: werd haar veel in de weg gelegd? Ook niet. Hilde Verbeek (1983) ging gewoon haar gang, koos zelden voor de gemakkelijkste weg en als ze al eens op haar gezicht ging, was dat vooral letterlijk. Zet een lantaarnpaal neer en ze loopt er tegenaan: “Ja, ik ben erg onhandig."

Zo moeilijk als ze fysieke obstakels ontwijkt, zo makkelijk neemt ze de academische horden. Neen de oratie bij de officiële aanvaarding van haar hoogleraarschap. Die zou normaliter in de aula van de Minderbroedersberg plaatsvinden. Maar daar zou vanwege de coronaregels maar een handjevol mensen naar binnen mogen.

En dus staat Verbeek op 9 juli op de preekstoel in de statige St. Janskerk, met deo en corona volente naar verwachting zo'n honderd gasten. “Ik heb gewoon gevraagd of het kon. Er zijn wel meer academische zittingen daar, met de dies natalis bijvoorbeeld, dus waarom niet? En het mocht!

Letterlijk op de preekstoel inderdaad, hoog verheven boven het publiek, maar echt preken ex cathedra zal ze niet. Juist niet, het druist in tegen al haar opvattingen over hoe wetenschap bedreven moet worden. Niet vanuit de ivoren toren maar met invloeden uit alle denkbare hoeken, ook tussen en met de mensen over wie het gaat.

"Dat heb ik vooral geleerd toen ik aan het promoveren was. Jan Hamers, Ruud Kempen en Erik van Rossum, mijn begeleiders, vertegenwoordigen drie verschillende disciplines waardoor ze samen to 
inzichten komen die ze apart nooit hadden bedacht. Dat is al één ding. Hun - en inmiddels ook mijn visie is: wetenschap, kennis, ontwikkel je samen met anderen. Wetenschap staat niet los van de maatschappij. Mijn onderzoek gaat over innovatie in de ouderenzorg, nieuwe woonvormen voor mense met dementie. Wie zijn dan relevant? In mijn orati noem ik ze: ouderen en hun naasten, professionals, bestuurders, docenten, zorgverzekeraars, ondernemers, studenten, beleidsmakers, gemeenten, architecten, woningbouwcorporaties. Input uit de praktijk is cruciaal. Bij dementie is de invalshoek vaak medisch: een hersenziekte. Maar als je een meer antropologisch perspectief erbij haalt gaat het ook over zingeving, ervaringen voelen mensen zich ergens thuis en waar ligt dat dan aan? Laat je voeden door de mensen zelf, da maakt je ideeën beter en je komt eerder bij de èchte vraagstukken uit; dat heb ik geleerd in onze onderzoeksgroep. Je moet als onderzoeker uit je comfortzone, ervoor zorgen dat je steeds uitgedaagd blijft, tunnelvisie en blinde vlekken vermijden."

Kapsones

Verbeek prijst zich gelukkig dat ze wetenschappelijk kon groeien in een omgeving waar kapsones niet op prijs worden gesteld: de Academische Werkplaats Ouderenzorg Limburg. "We hoeven niet per se te publiceren in het hoogste tijdschrift, maar er wordt wel van je verwacht dat je iets toevoegt, inhoudelijk iets bijdraagt. Dus niet minimaal twintig publicaties per jaar, wat sommige groepen normaal vinden,

terwijl dat, vind ik, helemaal niet kan! Wat gelukki ook ontbreekt is die houding van niks willen delen, andere onderzoekers als je vijanden zien; dat speelt bij ons niet. Haantjesgedrag, een hoogleraar die altijd op de voorgrond treedt, die overal zijn naam bij zet en jou je veren afpakt; zulke types zijn onze hoogleraren helemaal niet, juist het omgekeerde."

Het traditionele academische vechtmilieu is haar dus bespaard gebleven, waarbij de intrigerende vraag rijst of ze er overeind was gebleven. Tja, overeind, dat misschien wel, maar gelukkig? Dat zeker niet.

\section{Meisje}

Ze heeft drie broers boven zich van wie de jongste al zeven jaar ouder is.

"Een eenvoudig en heel traditioneel katholiek gezin in Valkenswaard. Mijn moeder komt uit een boerenfamilie en ging met 14 jaar van school, na het Voortgezet Gewoon Lager Onderwijs, mijn vader werkte op een salarisadministratie. Hij ging altijd op de fiets, een auto was er niet, we hadden het niet breed, gingen ook nooit op vakantie. Beiden zij heel gelovig, nog steeds, ze hadden allerlei rollen in de kerk. Ik heb het zelf ook allemaal doorlopen een bijbelclubje, de communie, het vormsel. Ik was het nakomertje. En het enige meisje, van mij werd nooit iets verwacht. Want dat hoeft niet bij meisjes hè? Toen ik havo/vwo advies kreeg en ik naar het vwo wilde, gymnasium zelfs, zei mijn moeder: 'Havo is goed genoeg hoor.' En toen ik later overwoog om geneeskunde te studeren was het: 'Doktersassistènte is toch ook leuk.' En toen ik naar Maastricht ging en op kamers wilde zei mijn moeder: 'Kind, blijf toch lekker hier wonen.' Is niet erg hoor, ik heb het allemaal gewoon gedaan, a heb ik wel een andere studie gekozen, en ze hebben me geen strobreed in de weg gelegd. Uiteindelijk steunden ze me in alles. Wilde ik geen jurkje maa een broekrok bij mijn communie? Mijn moeder vond het goed. Ik was best een beetje een jongensmeisje. En als puber heb ik veel ruzie met vooral mijn moeder gemaakt, ik was lastig. En streberig, ik wilde mijn plek bevechten. Als iemand dacht dat ik iets niet kon zou ik wel even bewijzen dat ik het wèl kon. Nog steeds."

Een voorbeeld? Ze heeft bij NWO een Vidi-aanvraag ingediend en onlangs een gesprek met de commissie gehad om haar onderzoeksvoorstel te verdedigen.
Had ze dan al een Veni-beurs, uit de welbekende trits Veni, Vidi, Vici? Gewoonlijk gaat die eraan vooraf Met een brede glimlach: “Nee, je hoeft niet per se eerst een Veni te hebben, er zijn uitzonderingen. Weet je, ik probeer het gewoon.

\section{Skibaan}

Ze las veel, op de basisschool tijdens vakanties soms wel drie boeken per dag. "Ik was een nerd, met van die dikke brillenglazen. Op de middelbare school heb je altijd van die clubjes; ik hoorde nergens echt bij en toch kon ik met iedereen opschieten. Ik ging gewoon mijn eigen gang, zal ook best wel gepest zijn maar haha, dat merkte ik dan niet."

Dat ze een beetje 'anders dan anderen' was, dat voelde ze wel. En ze had er ook wel mee geworsteld: wie ben ik? Maar hoe anders, dat merkte ze pas op de universiteit: "Dat was echt thuiskomen, daar liepen meer mensen rond zoals ik." Mensen met een intellectuele belangstelling, mensen die van boeken hielden: "Ik kom niet uit een belezen nest. Na de brugklas konden mijn ouders me niet meer met mijn huiswerk helpen

Maar ook: mensen uit een heel ander milieu. "Dan vertelde ik dat Fred, mijn vriend, een baantje had bij de skibaan in de buurt van ons dorp, en dan was de reactie: 'O, hebben je ouders een skibaan?' Ik wist 
niet wat ik hoorde. Ouders die een skibaan hebben! Dat werd normaal gevonden."

Het was dus wennen. Want de universiteit mag dan al lang geen elite-instelling meer zijn, de dominante cultuur is nog altijd, en zeker naarmate je hoger op de academische ladder klimt, van het keurig-burgerlijke soort. Daar moet je als eenvoudig Brabants dorpsmeisje niet al te geïmponeerd door raken.

Nu blijkt Verbeek niet iemand die zich snel laat

mponeren. Behept met een mengeling van naiveteit en onverstoorbaarheid ("iemand noemde mij ooit naturel en naïef") kijkt ze goed om zich heen: die mensen hier, hoe gedragen ze zich, hoe converseren ze, hoe reageren ze? Om zich er vervolgens niet al e veel van aan te trekken als de aanpassing niet naadloos verloopt: “Er zijn soms gala's of nette etentjes en ja, dan zit ik helemaal onder omdat ik dus niet kan eten, dat is die onhandigheid van mij. Ach, ik heb er niet zo'n last van hoor. Dan is het maa

\section{Hilde-charme}

Onhandig: een vriendin uit de wereld van de neuropsychologie bestempelde het ooit als het clumsiness syndroom. Voorbeelden te over: "Ik struikel veel, bots tegen lantaarnpalen, ik stapte ooit aan de ene kant van mijn fiets op om er aan de andere kant meteen weer vanaf te vallen. In groep zeven had ik een hersenschudding, een andere keer brak ik mijn pols omdat we met de fiets van een zandbergje af reden en ik viel. Mijn broer heeft me met zijn auto moeten halen. In Salou op vakantie met een vriendinnetje had ik alweer een grote schaafwond op mijn been opgelopen toen ze me dringend vroeg om te beloven dat ik nog maar drie domme dingen per dag zou doen."

Daarom, zegt ze, heeft ze naar aanleiding van de opmerking over haar clumsiness eens goed nagedacht. "Ik kwam tot de conclusie dat het mij buitenproportioneel veel moeite kost om me op dat soort dingen te concentreren. Ik denk altijd aan van alles en let niet op. En dus loop ik, als ik een hoek omsla, tegen de muur op. So be it. Autorijden kan ik, ik ben in één keer geslaagd en het gaat heel goed, behalve de bijzondere verrichtingen. Die kan ik niet" Medeweggebruikers zijn gewaarschuwd: het gaat hier onder meer over achteruit rijden in een rechte lijn, fileparkeren, de hellingproef. Maar ook dat zal ze vast wel weer oplossen met wat ze ironisch maar zelfbewust haar Hilde-charme noemt. De onhandigheid verheven tot wezenskenmerk.

\section{Seriemoordenaars}

"Ik ben psychologie in Maastricht gaan studeren omdat ik geïnteresseerd was in hersenen en gedrag: wat maakt dat we doen wat we doen? Dat kwam ook door de boeken die ik in mijn schooltijd las. Over een meisje dat het moeilijk had en bij de psychiater belandde. Depressieve jongeren, wat gebeurt daar in die hersenen? Ook seriemoordenaars fascinere me. Nee, het is niet dat ik mensen per se wil hèlpen en met ze wil praten, het gaat me er vooral om hoe het brein werkt. Vandaar de keuze voor Maastricht, hier is de psychologie biologisch gericht. En zo ben ik ook de richting van de neuropsychologie ingegaan en daarin afgestudeerd. Nu concentreer ik me op dementie, wat doet dat precies in het brein; daar weten we nog heel weinig van"

Omdat de klinische kant -Verbeek is ondanks haa 'biologische' voorkeur 'goed met mensen' - toch een beetje trok, volgde er een stage van een jaar in Psychiatrisch Centrum Vijverdal, “onder begeleiding van Rudolf Ponds, die heeft me geleerd hoe je onderzoek moet doen, hij is later hoogleraar in Amsterdam geworden".

Patiënten met niet-aangeboren hersenletsel, zoals die man met Korsakov die haar in het voorbijgaan luidkeels vroeg naar haar cupmaat en vervolgens of ze met hem wilde trouwen. Hij toen: "Nee? Oooo, ik maak me van kant!" Ze moet er nog om lachen, maar zo vrolijk was het verder allemaal niet. Interessant, dat wel, want ze deed onderzoek naar de behandelmotivatie van patiënten en belandd daarmee precies daar waar het voor haar om draait: wetenschap die zich voedt met echte mensen in de echte wereld, waar - in deze context - "de diagnose en de theorie samenkomen"

De ervaring in Vijverdal stuurde haar echter niet verder het pad op van de klinische praktijk, en ook latere ervaringen deden dat niet. Vanuit de AWO was Verbeek jarenlang een dag per week gestationeerd als linking pin bij de MeanderGroep (dezelfde die haar fulltime leerstoel betaalt), "daa heb ik bijvoorbeeld opgetrokken met psychologen en dan zie je dat een behandelrelatie vaak één op één is. Dat is niets voor mij, ik ben snel verveeld; steeds hetzelfde trucje doen, dat werkt voor mij niet. Ik heb een brede interesse, vind beginnen ook altijd leuker dan iets afmaken."

\section{Omgeving}

Snel verveeld? Terwijl bij haar thuis in de hal een juichende bruidsfoto hangt die van 12,5 jaar geleden dateert, terwijl de Fred op de foto diezelfde Fred is die ze al op de middelbare school kende en met wie 
Ze lacht: "Snel verveeld in mijn wèrk! Maar Fred is juist de stabiele factor, het vangnet waardoor ik me fijn voel en van daaruit mezelf kan vernieuwen. We zijn gezegend - ja, zo noem ik dat want het is echt niet vanzelfsprekend - met twee kinderen, Wout en Thomas, ze zijn nu zes en drie. Maar ik heb destijds wel mijn twijfels gehad; in mijn omgeving zag ik nooit vrouwen die een carrière met kinderen combineerden. Op zichzelf wilde ik het, maar tegelijkertijd zat ik er ook wel mee, heb er boeken over gelezen; wat voor moeder wil je zijn? Wat wil je ze meegeven? Als ik met iemand anders was geweest weet ik niet of ik nu moeder zou zijn maar Fred wilde het ook graag. Alleen, een oermoeder ben ik niet. Mijn conclusie is: kinderen hebben vooral een goede omgeving met liefdevolle relaties nodig, een moeder is niet per se het belangrijkste."

Fred, zegt ze, is het levende bewijs voor haar opvatting dat de mens in hoge mate door zijn omgeving wordt bepaald. "Hij maakt óók wie ik ben."

Het is een overtuiging die, in de context van haar werk, tot radicale uitspraken kan leiden. Want in het hele debat over de beste manier om ouderen met dementie te huisvesten durft ze de stelling wel aan dat "verpleeghuizen de mensen zieker maken". Zo heb ik het ook in mijn Vidi-aanvraag gezegd. Vandaar mijn interesse in zorgboerderijen. Daar is de omgeving anders ingericht, zowel fysiek als sociaa en je ziet dat mensen met dementie daar hee goed gedijen. Terwijl ze in het tehuis vaak binnen een maand aftakelen. Omdat ze er niet meer op hun potentie worden aangesproken, op wat ze nog kùnnen."

En, voegt ze eraan toe, "daar hoort ook bij dat deze ouderen zoveel mogelijk zelf blijven bepalen hoe hun leven eruitziet. Dat ze, waar het maar kan, regie en autonomie behouden."

\section{Afhankelijk}

Het is een echo van de ervaring die ze in 2011 als postdoc in Engeland opdeed, in het jaar na haa promotie. Een prozaïsche ervaring, moederziel alleen in een appartementje in Manchester " $\mathrm{ik}$ was met buikpijn vertrokken, waarom moest ik dit nou weer willen?"): ze zat gehurkt om de was uit de trommel te halen, stond op en verdraaide kennelijk haar knie. "Meniscus gescheurd, kruisbanden afgescheurd, alles zat vast."

Ze kon niet anders dan naar Nederland terugkeren omdat ze na de nodige operaties hulp nodig zou hebben. En dus moest ze trappen worden opgetild, hielp haar vader haar naar de wc, moest ze Fred voor het minste of geringste inschakelen. Na drie maanden ging ze terug naar Manchester, op krukke en met een inmiddels vergroeide rug.

"Uiteindelijk is het aardig goed gekomen maar als je dat allemaal meemaakt, als je zo afhankelijk bent van anderen, weet je hoe belangrijk het is om nog een beetje autonomie te hebben."

En toch, voegt ze er snel aan toe, sámen te zijn, "ik ben van de relaties tussen mensen, van de wederkerigheid. Niet van een samenleving die uit louter individuen bestaat. Je doet iets voor iemand, in mijn geval voor ouderen, en je wordt er zelf ook blij van.

Na het jaar waarin Verbeek drie operaties in nege maanden onderging en op allerlei manieren probeerde haar wetenschappelijke werk zo goed mogelijk in de lucht te houden, kreeg haar eerste promotor, Jan Hamers, van een gerenommeerde Maastrichtse hoogleraar op een dag een vraag voorgelegd. "Zeg, die Hilde, die is toch zo slim, dat is toch zo'n talent? Waarom publiceert ze dan nie meer?"
Het stak en het steekt haar nog steeds; ze zal er een paar keer op terugkomen. "Dat ging dan weer over die aantallen publicaties per jaar."

Te weinig output? Daar dachten ze bij de KNAW anders over. Vorig jaar werd ze gevraagd voo de Jonge Akademie: "Ik ben blij dat ik nu via dat podium de kans krijg om landelijk iets aan dit soort eisen te doen. En aan die mentaliteit."

Wammes Bos 


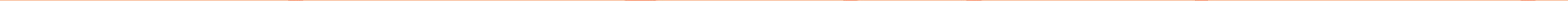


